IZA DP No. 7611

Expanding Export Variety: The Role of Institutional Reforms in Developing Countries

Liugang Sheng

Dennis Tao Yang

September 2013 


\title{
Expanding Export Variety: The Role of Institutional Reforms in Developing Countries
}

\author{
Liugang Sheng \\ Chinese University of Hong Kong \\ Dennis Tao Yang \\ University of Virginia, \\ Shanghai Jiao Tong University and IZA
}

Discussion Paper No. 7611

September 2013

\author{
IZA \\ P.O. Box 7240 \\ 53072 Bonn \\ Germany \\ Phone: +49-228-3894-0 \\ Fax: +49-228-3894-180 \\ E-mail: iza@iza.org
}

\begin{abstract}
Any opinions expressed here are those of the author(s) and not those of IZA. Research published in this series may include views on policy, but the institute itself takes no institutional policy positions. The IZA research network is committed to the IZA Guiding Principles of Research Integrity.

The Institute for the Study of Labor (IZA) in Bonn is a local and virtual international research center and a place of communication between science, politics and business. IZA is an independent nonprofit organization supported by Deutsche Post Foundation. The center is associated with the University of Bonn and offers a stimulating research environment through its international network, workshops and conferences, data service, project support, research visits and doctoral program. IZA engages in (i) original and internationally competitive research in all fields of labor economics, (ii) development of policy concepts, and (iii) dissemination of research results and concepts to the interested public.
\end{abstract}

IZA Discussion Papers often represent preliminary work and are circulated to encourage discussion. Citation of such a paper should account for its provisional character. A revised version may be available directly from the author. 


\section{ABSTRACT \\ Expanding Export Variety: The Role of Institutional Reforms in Developing Countries}

This paper presents theory and evidence showing that institutional reforms in developing countries can effectively expand their product varieties in export. Our model demonstrates that relaxing foreign ownership controls and improving contract enforcement can induce multinational companies to produce new products in host developing countries, and that a combination of the two reforms has an amplifying effect on the introduction of product varieties. Consistent with these theoretical predictions, we find empirically that ownership liberalization and judicial quality played an important role in raising the extensive margin of processing exports in China for the period of 1997-2007.

JEL Classification: D23, F14, L22

Keywords: export variety, ownership structure, contract environment, processing trade, policy reform, China

Corresponding author:

Dennis Tao Yang

Darden School of Business

University of Virginia

Charlottesville, VA 22903

USA

Email: YangD@darden.virginia.edu

\footnotetext{
* The authors would like to thank Pol Antras, Paul Bergin, Robert Feenstra, John Ries, Katheryn Russ, and Deborah Swenson for providing valuable comments and suggestions for an earlier version of this paper and to Jessie Pang for her competent research assistance. The authors are also grateful to the support of a Direct Research Grant provided by The Chinese University of Hong Kong and the research support from the Hong Kong Institute of Asia-Pacific Studies. We are responsible for all remaining errors.
} 


\section{Introduction}

Product variety plays an important role in the study of international trade and economic growth. The concept is fundamental because product variety is not only related to market structures and technological progress but also linked directly to consumer welfare. In the presence of significant expansion in trade, empirical studies have found that expanded import varieties contribute remarkably to the national welfare of importing countries (Broda and Weinstein, 2006), whereas the rise in export varieties is associated with productivity improvement for exporting economies (Feenstra and Kee, 2008). Moreover, what to produce and what to export also have growth implications for a developing economy. As Hausmann et al. (2007) argues, countries that produce and export more sophisticated products tend to grow faster than countries that specialize in unsophisticated,"poorcountry" goods. The ability to produce a wide range of products becomes even more important in the age of global production sharing because multinationals are more likely to invest in regions with a wide range of products and thus easy access to intermediate inputs.

Given the importance of the extensive margin in trade, existing studies have provided much insight into the determination of export variety. Models of monopolistic competition implies that larger economies usually export more varieties (Krugman, 1981), a prediction which has received empirical support (Hummels and Klenow, 2005). In trade models that emphasize productivity differences across firms (Eaton and Kortum, 2002; Melitz, 2003), variables such as factor endowments, trade barriers, distance, and transport costs are important determinants of the range of goods for export. However, to our knowledge, there have not been systematic analyses of the role of host country institutions and policies in affecting product varieties in export. Perhaps the exceptions are Goldberg et al. (2010) and Debaere and Mostashari (2010) who have shown that reductions in import tariffs can help firms expand their domestic product scope and the range of goods in trade.

The main purpose of the current paper is to study the effects of host country institutions and policies on the introduction and exporting of new goods in developing countries. We incorporate the role of contract enforcement and ownership liberalization of foreign direct investment (FDI) into a model of international production sharing (Antràs, 2005; Antràs and Helpman, 2008). 
We show that when the host government imposes ownership restrictions on foreign investment, outsourcing through market transactions is the dominant form of global production, which limits product varieties brought to the South. With the removal of ownership restrictions, however, multinational companies have incentives to expand their product varieties to the South through their foreign-owned affiliates. Moreover, the improvement of contract environment in a developing country reduces the efficiency loss because of the "holdup" problem involved in incomplete contracts, thus inducing the inflow of new products through foreign multinationals. While improvement in each type of institution raises the extensive margin in production and export, the liberalization of ownership structures along with the better enforcement of contracts can have an amplification effect on the development of new products in the South. ${ }^{1}$

We test the implications of the model based on the experience of China, where major institutional reforms occurred concurrently with the dramatic expansion of processing trade in the period of 1997-2007. To quantify the effect of institutional improvements on the extensive margin of processing exports, we construct a measure of ownership liberalization at the industry level, employing a systematic policy change in which the Chinese government gradually lifted the restrictions on ownership structures governing FDI. During this period, China expanded the list of "encouraged" industries for FDI while reducing the number of "restricted or prohibited" industries, aiming to lift the restrictions on foreign capital inflows as the country got accession to the World Trade Organization (WTO). This category was first published in 1995 and subsequently revised four times between 1997 and 2007 (NDRC, various years). These policy changes present a unique opportunity for us to test the effect of relaxing FDI restrictions on trade patterns across firms of different organizational forms. ${ }^{2}$ In addition, we use an index of judicial efficiency from the World Bank (2008) to approximate the degree of contract enforcement. To measure the export variety of

\footnotetext{
${ }^{1}$ In the context of product cycle, Antras (2005) shows that the emergence of vertically integrated production by multinational firms helps accelerate the shift of production toward the South. He also suggests that liberalizing FDI restrictions can speed up the product cycle. Building on these insights and findings, we consider jointly the effects of FDI liberalization and contract enforcement in a model and conduct empirical analysis in a large developing economy.

${ }^{2}$ A similar index for 1997 and 2002 is first developed by Blonigen and Ma (2010), which examines the effect of ownership regulations on the composition of Chinese exports. We expand this index to 1995, 2004, and 2007, and investigate the effects of these policies on the export product varieties.
} 
processing trade, we use an index of the extensive margin formulated by Feenstra and Kee (2008).

Our empirical results focus on the effects of policy reforms on the variety of processing exports. We find that encouragement policies towards foreign firms significantly increase the variety of processing export, and they have a much larger effect on the variety of export by foreign-owned enterprises (FOEs). Consistent with our model, improvements in contract environment do not enhance product development through outsourcing export, but they have a strong positive effect on product transfers by FOEs. Moreover, we find an amplification effect from the coordination of reforms. The Chinese data show that contract enforcement and ownership liberalization are complementary to each other in product development by foreign-owned firms: the effect of one reform is larger, if the quality of the other institution is higher. These results are robust to alternative specifications. The strong interaction effect of contract enforcement and ownership liberalization suggests that both reforms in combination are important for expanding product varieties in developing countries.

Our new empirical finding that FDI liberalizations lead to higher growth of export varieties by foreign-owned firms, particularly in regions with better contracting environments, is consistent with property-rights theory of multinational boundaries (Antràs and Helpman, 2008; Antràs, 2012). More multinational firms would choose to integrate global production as the contractibility of the South improves. This view forms a contrast with the transaction-cost theories of firm boundaries, which predict that multinationals prefer vertical integration in weak contracting environments in order to protect their technology or knowledge (Markusen, 1995). Our finding is opposite to the transaction-cost prediction but supportive of the property-rights theory.

Our paper is also related to studies on host country institutions and policies that influence trade patterns, rates of innovations and FDI. These policies include the enforcement of intellectual property rights (e.g., Chin and Grossman 1990; Diwan and Rodrik 1991; Glass and Saggi 1998), government subsidies to innovation and imitation (e.g., Grossman and Helpman 1991), and institutional variables such as corporate tax rates and bureaucratic delays and corruption (e.g., Gastanaga et al. 1998; Wei 2000). However, none of these studies focuses on the consequences of host 
government ownership restrictions on product transfers to developing countries.

The current paper is structured as follows. Section II develops a simple model that shows how the removal of ownership restrictions and improvement in legal enforcement may expand export product varieties in the South. We analyze the effect of each policy reform and their amplifying interactive effects. Section III explains the construction of the measures of policy reforms and presents our empirical findings. Section IV concludes.

\section{The Model}

This section relies on the global sourcing model of Antràs (2005) and Antràs and Helpman (2008) to investigate the consequences of relaxing ownership restrictions and improving contract enforcement on expanding product variety in developing countries. ${ }^{3}$ The international business literature has long emphasized the prevalence of government's ownership restrictions on multinational companies in developing countries (e.g., Kobrin 1987; Gomes-Casseres 1990), and a large body of economics literature has studied the role of contract enforcement in determining the volume of FDI (e.g., Gastanaga et al. 1998; Wei 2000). Our model shows how host country reforms in ownership regulations and judicial efficiency can effectively expand export product varieties. Moreover, the model generates four testable predictions that provide a basis for subsequent empirical analysis.

\subsection{Setup}

The world consists of two countries, the North and the South. Labor is the unique factor of production, which cannot move across the border. Suppose goods can be free traded without any

\footnotetext{
${ }^{3}$ Different from their studies, we model partial incomplete contracts explicitly in a stochastic environment, and thus the roles of contract environment and ownership liberalizations of foreign capital are distinct in our framework. Several other papers, including Antràs and Helpman (2008), Acemoglu et al. (2009), and Levchenko (2007), also model partial incomplete contracts. Our approach is close to Acemoglu et al. (2009).
} 
costs, and the demand function for a particular good $z$ is given by

$$
y(z)=\lambda p(z)^{-1 /(1-\alpha)}
$$

where $\lambda$ is a function of total expenditure and an aggregate price index, as shown in the general equilibrium model in Appendix. Hence, $p(z)=(\lambda / y(z))^{1-\alpha}$ and the revenue is $R(z)=$ $\lambda^{1-\alpha} y(z)^{\alpha}$.

The final-good producer needs headquarter service $(h)$ and an intermediate input $(m)$ to produce each unit of output. The production function of the final-good is

$$
y(z)=\left(\frac{h}{1-z}\right)^{1-z}\left(\frac{m}{z}\right)^{z}, \quad 0 \leq z \leq 1
$$

where $z$ represents the intensity of the intermediate input in the production. As such, $z$ is interpreted as an indicator of standardization of the good production.

Headquarter service provided by the final-good producer is assumed to be produced only in the North. The intermediate input provided by the supplier can be produced both in the North and in the South. The production of one unit of headquarter service and intermediate input each requires one unit of labor input. However, there is an iceberg trade cost associated with the export of the intermediate input in the South: one unit of sale to the North requires $\tau>1$ units of production in the South.

The final-good producer needs to contract with an intermediate-input supplier to produce the final-good. She can either purchase the intermediate input from an independent manufacturing plant or obtain it from an integrated plant. The investment is assumed relation specific; the finalgood producer tailors the headquarter service, and the supplier customizes its intermediate input. Thus, both parties' inputs are useless outside the relationship. As the final-good producer begins the contracting process, the supplier needs to pay a lump-sum transfer $T$ because ex ante a large number of identical and potential manufacturers of the good exist. This lump-sum transfer can make the suppler break even. Therefore, the contract consists of two organizational choices 
$O \in\{V, A\}$ : vertical integration and arm's length market transaction. Vertical integration implies that the Northern producer employs the supplier and owns the intermediate input, and market transaction implies that the supplier is an independent plant who owns the intermediate input. Thus, if multinationals offshore, we call Southern export through vertical integration "FDI export", whereas export through independent firms as "outsourcing export". Following the classical incomplete contract theory, we assume that organizational form is always contractible and that the contractibility of input investment depends on a country's legal system.

To characterize explicitly the effect of contract environment on product transfers to the South, we depart from Antràs (2005) by introducing a probability of a complete contract. Following Acemoglu et al. (2009), we assume that the probability of completing the contract is $\phi_{c}$, where $c \in\{N, S\}$, and $\phi_{c} \in[0,1]$. As the North has a better legal system and higher ability for legal enforcement, it is reasonable to assume $\phi_{N}>\phi_{S}$. Without the loss of generality, we assume $\phi_{N}=1$, i.e., the contract is complete in the North. Without introducing confusion, we ignore the subscript of $S$ in $\phi_{S}$.

The timeline of events is summarized as follows:

1. The final-good producer chooses to locate the supplier from country $c \in\{N, S\}$ and offers a contract $\{O, m, T\}$ to the supplier.

2. The supplier decides whether to accept or reject the offer. If accepting, he makes the lumpsum transfer $T$ to the final-good producer.

3. Following acceptance of the contract, there is probability $\phi_{c}$ by which the contract is upheld. With probability $1-\phi_{c}$, the contract is not upheld; then, bargaining will occur between the final-good producer and the supplier after the product is produced.

4. After the uncertainty is revealed, $h$ and $m$ are produced.

5. If the contract is upheld, the final-good producer receives the customized intermediate input provided by the supplier. Then, the producer manufactures the final-good, and sells it. 
6. If the contract is not upheld, the producer and the supplier bargain over the revenue. If Nash bargain breaks, no output is produced. If a successful Nash bargain occurs, then the producer pays the supplier for the intermediate input, produces the final-good, and sells it.

The subgame perfect equilibrium (SPE) can be described by a tuple $\left\{O^{*}, c^{*}, T^{*}, h^{*}, m^{*}, y^{*}\right\}$, where $O^{*}$ denotes the optimal organizational form, $c^{*}$ denotes optimal location choice, $T^{*}$ is the optimal size of the lump-sum transfer, and $\left(h^{*}, m^{*}, y^{*}\right)$ are optimal input levels and the corresponding output of good $z$. The equilibrium can be solved backwards.

We now consider the decision of a final-good producer of good $z$ who needs to find a supplier either in the North with higher wage $w^{N}$ or in the South with lower wage $w^{S}$, taking other producers' behavior as given.

\subsection{Supplier in the North}

As the contract is complete in the North, the organizational choice is irrelevant by the nature of the incomplete contract theory. Under this scenario, the producer requests the supplier to provide the intermediate input $m$ and her own headquarter service $h$ to maximize profit,

$$
\begin{aligned}
& \max _{h, m} \pi=R-w^{N} h-w^{N} m \\
& \text { s.t. } R=\lambda^{1-\alpha} y^{\alpha}
\end{aligned}
$$

which yields the first-best investment of $m^{*}$ and $h^{*}$. The producer pays the supplier $w^{N} m^{*}$, and sets the lump-sum transfer $T=0$. The producer has the following profit:

$$
\pi^{N}(z)=(1-\alpha) \lambda\left[\alpha / w^{N}\right]^{\alpha /(1-\alpha)}
$$




\subsection{Supplier in the South}

If the producer chooses to offshore the intermediate input from the South, she faces the uncertainty of contract environment. With probability $\phi$, the contract is complete; thus, the producer can achieve the first-best inputs $m^{*}$ and $h^{*}$. However, with probability $1-\phi$, the contract is incomplete; then the ex ante contracted input investments are not upheld. In this case, both parties will under-invest their inputs because of the hold-up problem. Given the optimal investment bundles in the two scenarios, the producer will set the lump-sum transfer $T$ equal to the expected profit of the supplier. The producer maximizes the expected profits by choosing the optimal organizational form.

We first solve the sub-equilibrium in stages 5 and 6 , as the uncertainty of contract environment is revealed, and then compute the expected profits under different choices of organizational form. At stage 5, because the contract is upheld in the South, we can follow the case of complete contract in the North by solving the following problem:

$$
\begin{aligned}
& \max _{h, m} \pi=R-w^{N} h-\tau w^{S} m \\
& \text { s.t. } R=\lambda^{1-\alpha} y^{\alpha}
\end{aligned}
$$

which yields the following profits for the producer: $\tilde{\pi}_{c}^{S}(z)=(1-\alpha) \lambda\left[\alpha\left(1 / w^{N}\right)^{z}\left(1 /\left(\tau w^{S}\right)\right)^{1-z}\right]^{\alpha /(1-\alpha)}$.

At stage 6, the contract is not upheld in the South. The producer and the supplier know that they will renegotiate their revenue shares after making the investment. Thus, the supplier chooses intermediate input $(m)$ to maximize revenue minus cost (including shipping cost), and the producer chooses headquarter service $(h)$ to maximize her own revenue minus cost. They also know that their revenue depends on consumer demand and the simultaneous investment of the other party. Suppose the producer's revenue share is $\beta \in[0,1]$. The value of $\beta$ depends on the organizational form, as we will discuss below. 
Therefore, the supplier chooses intermediate input $m$ to solve the following problem:

$$
\begin{aligned}
& \max _{m} \pi=(1-\beta) R-\tau w^{S} m \\
& \text { s.t. } R=\lambda^{1-\alpha} y^{\alpha}
\end{aligned}
$$

Similarly, the producer chooses headquarter service $h$ to solve the following problem:

$$
\begin{aligned}
& \max _{h} \pi=\beta R-w^{N} h \\
& \text { s.t. } R=\lambda^{1-\alpha} y^{\alpha}
\end{aligned}
$$

The solutions to these two problems will yield optimal headquarter service $h(\beta)$ and intermediate input $m(\beta)$. The corresponding profits for the producer and the supplier in stage 6 are $\tilde{\pi}_{1}^{S}(z, \beta)=$ $\beta R(h(\beta), m(\beta))-w^{N} h(\beta)$, and $\tilde{\pi}_{2}^{S}(z, \beta)=(1-\beta) R(h(\beta), m(\beta))-\tau w^{S} m(\beta)$.

At stage 3, the contract environment is unknown to the producer and supplier; thus, their expected profits are the weighted profits from stages 5 and 6 . Hence, the producer can set the lumpsum transfer $T$ equal to the supplier's expected profits $\left[\phi * 0+(1-\phi) \tilde{\pi}_{2}^{S}(z, \beta)\right]$. Thus, if the producer chooses the Southern supplier, her expected profit at stage 1 is

$$
\begin{aligned}
\pi^{S}(z, \beta) & =\phi \tilde{\pi}_{c}^{S}(z)+(1-\phi) \tilde{\pi}_{1}^{S}(z, \beta)+T \\
& =\phi \tilde{\pi}_{c}^{S}(z)+(1-\phi) \tilde{\pi}_{1}^{S}(\beta, z)+(1-\phi) \tilde{\pi}_{2}^{S}(z, \beta) \\
& =\phi \tilde{\pi}_{c}^{S}(z)+(1-\phi) \tilde{\pi}^{S}(z, \beta)
\end{aligned}
$$

where

$$
\begin{aligned}
\tilde{\pi}^{S}(z, \beta) & =\tilde{\pi}_{1}^{S}(z, \beta)+\tilde{\pi}_{2}^{S}(z, \beta) \\
& =R(h(\beta), m(\beta))-w^{N} h(\beta)-\tau w^{S} m(\beta) \\
& =\lambda[1-\alpha \beta(1-z)-\alpha(1-\beta) z]\left[\alpha\left(\beta / w^{N}\right)^{1-z}\left((1-\beta) /\left(\tau w^{S}\right)\right)^{z}\right]^{\alpha /(1-\alpha)} .
\end{aligned}
$$




\subsection{Offshoring and Ownership Choice}

With a decision to offshore its intermediate input to the South, the Northern producer needs to choose an organizational form: vertical integration ("FDI export") or market transaction ("outsourcing export"). We assume a symmetric Nash bargain in relation-specific investment. According to Grossman and Hart (1986), the choice of organizational form affects the parties' outside values. For market transaction, both agents have control over their own inputs, with zero outside values once the Nash bargain breaks up. This condition implies an equal revenue share for each agent, thus $\beta^{A}=1 / 2$. However, in vertical integration, the producer owns the plant, and the supplier is an employee. If the supplier does not provide the intermediate input with sufficient quality, the producer can fire the supplier, who will be left with nothing, and seize the intermediate input $m$. The producer can still obtain a fraction $\delta \in(0,1)$ of the output, which in turn generates sale revenue of $\delta^{\alpha} R$. The quasi-rent of this relationship is $\left(1-\delta^{\alpha}\right) R$. Symmetric Nash bargaining leaves each party with its outside option plus one-half of the quasi-rent. Hence, the producer's $e x$ post share in sales revenue is $\beta^{V}=\frac{1}{2}\left(1+\delta^{\alpha}\right)$. Consequently, we have

$$
1>\beta^{V}>\beta^{A}=1 / 2 .
$$

The Northern producer chooses production locations, as well as the optimal offshoring organizational form. Therefore, her ex ante expected profit is

$$
\pi(z)=\max _{c \in\{N, S\}, O \in\{V, A\}}\left\{\pi^{N}(z), \pi^{S}\left(z, \beta^{A}\right), \pi^{S}\left(z, \beta^{V}\right)\right\} .
$$

It can be shown that

$$
\left(\frac{\pi^{N}(z)}{\pi^{S}\left(z, \beta^{O}\right)}\right)^{\frac{1-\alpha}{\alpha z}}=\frac{B^{O}(z)}{\omega / \tau}
$$

where

$$
B^{O}(z)=\left[\phi+(1-\phi) \frac{1-\alpha \beta^{O}(1-z)-\alpha\left(1-\beta^{O}\right) z}{1-\alpha}\left[\left(\beta^{O}\right)^{1-z}\left(1-\beta^{O}\right)^{z}\right]^{\alpha /(1-\alpha)}\right]^{-\frac{1-\alpha}{\alpha z}}
$$


and $O \in\{V, A\}$ and $\omega=w^{N} / w^{S}$. Hence, for a given $z, \pi^{N}(z)>\pi^{S}\left(z, \beta^{O}\right)$ if and only if $B^{O}(z)>\omega / \tau$, and $\pi^{S}\left(z, \beta^{V}\right)>\pi^{S}\left(z, \beta^{A}\right)$ if and only if $B^{V}(z)<B^{A}(z)$.

Figure 1 shows the coexistence of the three types of production modes: exclusive production in the North, vertical integration across the border, and arm's length production sharing. For $\delta^{\alpha}<$ 1/2, we can obtain the following key lemma of Antràs (2005) (see the proof in Appendix A):

Lemma 1 For the most headquarter-service-intensive (least-standardized) goods, the intermediate inputs remain in the North. For the relatively more headquarter-service-intensive goods, the intermediate inputs are offshored to the South through vertical integration. For the least headquarter-service-intensive goods, the intermediate inputs are outsourced to the South.

Note that under certain conditions, vertical integration may not be an optimal arrangement for the supply of the intermediate input. For instance, if the $\omega / \tau$ line goes through the intercept of $B^{V}$ and $B^{A}$ curves, the production in the North and outsourcing to the South will dominate vertical integration. Vertical integration is also not optimal if the trade cost is too high, which lowers the $\omega / \tau$ line below the $B^{V}$ curve, or if the contract enforcement is too poor, which raises the $B^{V}$ curve above the $\omega / \tau$ line. The coexistence of the three organizational forms provides a rich analytical framework.

Our primary interest is to examine the role of host country policy reforms in affecting product range of the developing countries. In what follows, we will investigate how the relaxation of ownership restrictions for foreign capital inflows, improvements in contract enforcement, and reduction in trade cost affect product variety in the South.

Governments in developing countries often restrict the activities of wholly-owned foreign invested firms for reasons including reducing competition with indigenous firms, promoting technology transfer through joint ventures, and controlling strategic sectors (e.g., Kobrin 1987; GomesCasseres 1990). In an extreme case of a strict prohibition of wholly-owned foreign firms, the dotted $B^{V}$ curve would disappear from Figure 1. As a result, only "outsourcing export" would take place. Under this situation, the cutoff between Northern and Southern productions is $\bar{z}_{N A}$. 
If the ownership restriction is removed, $B^{V}$ becomes part of the choice set. Therefore, the cutoff between North and South productions moves left to $\bar{z}_{N V}$, i.e., more goods will be offshored to the South through vertical integration. However, the extensive margin of outsourcing export will be reduced because the supply of some goods will be switched from arm's length production to vertical integration. We summarize these effects of ownership liberalization in the South as the first hypothesis:

Result 1 Ownership liberalization, which allows vertical integration in the South, increases the extensive margin of FDI export but reduces the extensive margin of outsourcing export. As a result, the total varieties of Southern export increases.

An improvement in contract environment can be characterized by an increase in $\phi$. As Figure 2 shows, a larger $\phi$ shifts down the $B^{A}$ and $B^{V}$ curves, thus raising the extensive margin of FDI export. However, because the intercept between $B^{A}$ and $B^{V}$ is independent of $\phi$, the extensive margin of outsourcing export does not change. ${ }^{4}$ We state the second hypothesis as follows:

Result 2 Better contract enforcement (a rise in $\phi$ ) increases the extensive margin of FDI export, but it has a neutral effect on the product variety of outsourcing export. As a result, the extensive margin of Southern export increases.

This result is consistent with the property-rights theory of multinational boundaries (Antràs and Helpman, 2008; Antràs, 2012), which predicts that more firms with a larger range of headquarter intensive content will choose to integrate their global production, as the contractibility of Southern suppliers improves. Thus, ownership liberalization would lead to higher growth of FDI exports particularly in better contracting environments. By contrast, transaction-cost theories of firm boundaries predict that multinationals prefer vertical integration in weak contracting environments in order to protect their technology or knowledge (Markusen, 1995). Therefore, ownership liberalization would increase FDI exports particularly in weak contracting environments.

\footnotetext{
${ }^{4}$ The derivation of this result is based on the assumption of zero profit of suppliers, but it still holds even the suppliers get positive rents, if their rents under complete or incomplete contracts are independent of $\beta$. Otherwise further discussions on the endogenous determinants of the suppliers' rents are needed, such as in Basco (2010). Analysis along this direction goes beyond the scope of the current paper, which we leave for future research.
} 
Given the consequences of individual reforms in Results 1 and 2, exploring the effects of coordinated reforms is also important. If the South relaxes its ownership controls in combination with improvements in legal systems, growth in the extensive margin through FDI export can be even larger. Figure 2 shows that the effect of ownership liberalization increases extensive margin in the South from $\bar{z}_{N A}$ to $\bar{z}_{N V}$ when the contract environment is poor. As the contract environment improves, the effect of ownership liberalization becomes $\bar{z}_{N V}^{\prime}-\bar{z}_{N A}^{\prime}$. Thus, FDI liberalization has a larger effect with the better contract environment if the inequality $\left(\bar{z}_{N V}^{\prime}-\bar{z}_{N A}^{\prime}\right)>\left(\bar{z}_{N V}-\bar{z}_{N A}\right)$ holds. ${ }^{5}$ Moreover, ownership liberalization may also enhance the effect of improving the contracting environment. As Figure 2 shows, the improvement in contracting will increase the extensive margin from $\bar{z}_{N A}$ to $\bar{z}_{N A}^{\prime}$ if only arm's length transaction is allowed, whereas it increases the product range from $\bar{z}_{N V}$ to $\bar{z}_{N V}^{\prime}$ if FDI ownership restriction is removed. Thus, FDI liberalization can enhance the effect of improving contractibility on the extensive margin if the inequality $\left(\bar{z}_{N V}^{\prime}-\bar{z}_{N A}^{\prime}\right)>\left(\bar{z}_{N V}-\bar{z}_{N A}\right)$ holds.

This framework suggests that contract enforcement and ownership liberalization can be complementary factors for product transfers in FDI export: the effect of one reform is larger if the quality of the other institution is higher. This possible amplification effect is summarized as follows:

Result 3 (Amplification Effect) Under the condition $\left(\bar{z}_{N V}^{\prime}-\bar{z}_{N A}^{\prime}\right)>\left(\bar{z}_{N V}-\bar{z}_{N A}\right)$, coordinated reforms in ownership liberalization and contract enforcement mutually enhance the effects of each other and amplify the growth of the extensive margin through FDI export in the South.

Trade cost reduction is characterized by a decrease in $\tau$. As Figure 2 shows, a fall in $\tau$ shifts up the horizontal line $\omega / \tau$. This movement raises the extensive margin of FDI export, as shipping back the intermediate good produced in the South is now cheaper. However, because the cutoff between vertical integration and outsourcing remains the same as before, the extensive margin of arm's length arrangement does not change. The following is a straightforward result:

\footnotetext{
${ }^{5}$ An implicit assumption is that products are uniformly distributed over $z$. Relaxing this assumption only requires to a slight change in the condition, i.e. $\int_{\bar{z}_{N A}^{\prime}}^{\bar{z}_{N V}^{\prime}} f(z) d z>\int_{\bar{z}_{N A}}^{\bar{z}_{N V}} f(z) d z$, where $f(z)$ is the density function of the product distribution over $z$.
} 
Result 4 Reduction in trade cost (a fall in $\tau$ ) increases the extensive margin of FDI export, but it has a neutral effect on the extensive margin of outsourcing export. As a result, the extensive margin of Southern export increases.

In appendix B, we show that the above results derived from a partial equilibrium remain valid in the general equilibrium with free entry. The main difference is that the growth in the extensive margin due to policy changes will be reduced because the relative wage in the South increases in the case of a general equilibrium. This is due to rising labor demand as more production is offshored from the North. However, the general equilibrium effect is likely limited when we consider a small open economy or a country like China with abundant supply of cheap labor.

\section{Empirical Analysis}

\subsection{Data and Key Variables}

We test the implications of the model against the Chinese experience when major institutional reforms occurred concurrently with the dramatic expansion of processing trade surrounding China's entry into the WTO. The primary data source we use is the Chinese customs trade data for the period of 1997-2007. The dataset records both the value and quantity of trade at the product level (eight-digit HS code), export locations, firm ownership category, and type of Chinese custom regimes. Our analysis focuses on processing export because it is an integrated part of global production sharing. Processing export is an activity that involves a firm in China importing intermediate input from aboard, processing it with other local productive factors, and then exporting the finished goods to international markets. Imported intermediate input is duty-free as long as it is only used for export (Feenstra and Hanson, 2005). In other words, it is the offshored production from developed countries. Processing trade plays a major role in China's international trade, accounting for about 55 percent of total export for the 1997-2007 period.

The firm ownership types in the trade data include Chinese-owned domestic firms, joint ventures, and wholly-owned foreign firms. We consider wholly-owned foreign firms as vertically 
integrated affiliates and the other two types of ownership as outsourcing.

Our definition of variety is an eight-digit HS product-destination country pair, namely, a product exporting to one particular country. For empirical analysis, China is treated as the South, whereas the rest of the world is treated as the North. For robustness checks, we use high-income countries as the North and define variety as an eight-digit HS product. Our main empirical results are very robust to these alternative variable definitions.

The extensive margin can be simply measured as the number of varieties. However, this measure ignores the volume weights of export for different varieties. Therefore, we follow Feenstra and Kee (2008) (thereafter FK index) to construct an extensive margin measure, which takes export weights into account. It also has the advantage of comparability over time, across regions and firm organizational forms. The extensive margin is defined as the following $\Lambda$ ratio:

$$
\Lambda_{i o t}^{r}=\frac{\sum_{j \in J_{i o t}^{r}} v_{i}^{F}(j)}{\sum_{j \in J_{i}^{F}} v_{i}^{F}(j)}
$$

where $j$ denotes a product, and $J_{i o t}^{r}$ is the set of products that province $r$ exports in industry $i$ through organizational form $o$ in year $t$. We define $J_{i}^{F}=\bigcup_{r, o, t} J_{i o t}^{r}$ as the total set of products that China exported to the rest of the world in industry $i$ over all sample years. $v_{i}^{F}(j)$ is the average value of export for product $j$ (i.e., summed over all provinces and organizational forms and averaged across years). Note that this measure of the extensive margin changes over time or across provinces or organizational forms only if there is a change in the set of export goods in that province or that type of firm, $J_{i o t}^{r}$. The denominator of the ratio is constant over time, across provinces and organizational forms. By taking the union of all China's exported products over the years, we obtain a consistent comparison across all three dimensions. The value of $\Lambda_{i o t}^{r}$ is in the interval of $[0,1]$.

Table 1 presents the summary statistics of China's processing export and its extensive margin by organizational forms. The first two columns show that China's processing export has increased dramatically since its accession to WTO in 2001 and that most of this increase is attributable to 
wholly-owned foreign firms. During this 11-year period, the share of processing exports by wholly foreign owned firms increased from 29 percent to 64 percent. The extensive margin, measured by both number of varieties and FK index, also increased dramatically. A noticeable trend is that the extensive margin of wholly foreign owned firms gradually caught up with the extensive margin of outsourcing firms. Whereas export product varieties through FDI was systematically below that of outsourcing in the late 1990s, the gap had been almost entirely eliminated by 2007.

The rising role of export by wholly foreign owned firms in China is a consequence of ownership liberalization for foreign capital in the face of China's accession to WTO in 2001. Wholly foreign-owned companies were restricted or prohibited in China in the 1990s, whereas joint ventures were encouraged. The main target of such policy was to maximize the access to foreign advanced technologies, as it was perceived that learning costs were much lower within joint ventures. However, China undertook a major regulatory reform regarding foreign trade and investment in the face of the WTO accession in 2001. The WTO Agreement on Trade-Related Investment Measures (TRIMs) explicitly precludes WTO members from imposing restrictions or distortions on foreign investment. To comply with the provisions of the TRIMs agreement, China modified many laws regulating trade and foreign investment, encouraging foreign firms to compete on an equal basis with Chinese companies. ${ }^{6}$ These policy reforms resulted in changes in the ownership structures of FDI to China. Joint ventures played the dominant role in foreign direct capital inflows before 2001. However, wholly foreign-owned firms have accounted for 78 percent by 2008 (NBS, 2009b).

We construct a unique measure of ownership liberalization using the official list from the Chinese government that specifies which industries are encouraged, restricted, or prohibited for foreign investment. This list, provided in the Catalogue for the Guidance of Foreign Investment Industries (NDRC, various years), was first published in 1995 and was revised subsequently in 1997, 2002, 2004, and 2007. For encouraged industries, foreign investors have more freedom in choosing their ownership structures, and they enjoy other advantages such as preferable corporate tax rates, low costs of land, and duty-free for imported inputs. In contrast, for restricted or

\footnotetext{
${ }^{6}$ See Branstetter and Lardy (2008) for detailed discussions on China's policy changes upon its WTO accession.
} 
prohibited industries, the Chinese government usually imposes stringent restrictions on ownership structures and high entry cost for foreign investors. ${ }^{7}$

The listed industries or products under encouragement or restriction policies follow roughly the structures of the China Standard Industrial Classification (CSIC) at four digits level, however, each listed item could be possibly matched with multiple industries (at four digits level). Based on a systematic key word search, an industry is identified as under the coverage of encouragement (or restriction) policy if a listed item matches with that industry under CSIC(2002), a method consistent with Blonigen and Ma (2007). ${ }^{8}$

To provide an overview of the ownership liberalization process, we count the number of industries under encouragement and restriction policies in the four digits of the 2002 CSIC for each year. The results are presented in Figure 4. The data show a clear trend of ownership liberalization for foreign capital from 1995 to 2007. Two major expansion of encouragement policy are found in 2002, the year after China's accession to WTO, and in 2007, the deadline that the Chinese government promised to remove most of the trade and investment protections. Only 54 out of the 482 industries in manufacturing sector still have had restrictions for foreign capital by the end of 2007. However, those restrictions were only imposed on a very few specific products related to China's traditional culture.

For subsequent regression analysis, we construct two proxies for ownership liberalization at

\footnotetext{
${ }^{7} \mathrm{An}$ important issue is whether China's industrial policies on foreign capital target on promoting export. If industries in the encouraged categories have the highest potential in export growth and thus the government selects those industries as the encouraged ones, the encouragement policy variable would be endogenous in our later empirical analysis. However,it is unlikely that the Chinese government specifically chose to encourage FDI in industries with the greatest export potential. FDI ownership liberalization in China was largely the consequence of China's entry into WTO. To comply with the WTO Agreement on TRIMS, the Chinese government removed ownership restrictions on most industries in the manufacturing sector, except those industries that were highly pollutant or dependent on Chinese traditional manufacturing techniques. Meanwhile, the government also encouraged foreign investment in advanced technologies, sustainable resources and environmental protection, for which China usually do not have a comparative advantage. There is no obvious relationship between the encouragement policy and export potential.

${ }^{8}$ We use two documents to identify the associated CSIC industrial codes for the key words: CSIC(2002) and Product Classification for Statistics (PCS) (NBS, 2005). The PCS(2005) is based on CSIC(2002), but it is more disaggregated, containing more than 34,000 products at the 10-digit level. We match the Catalogue with industrial classifications rather than individual products because this method is much more reliable. For instance, "Diary products" are on the encouragement list, and it corresponds exactly to industry 1440 in CSIC(2002). However, it is difficult to match this product to commodity names in the HS system. Even if the matching can be carried out through certain approximation method, the matching would be less accurate.
} 
the industry level: an encouragement policy indicator and a restriction (includes prohibited) policy indicator. We assign the value of 1 for encouragement (or restriction) policy in an industry if at least one product in that industry is formally stated on the government list of encouragement (or restriction). Otherwise, we assign the value of 0 to that industry. Thus, these two policy indicators capture the differences in ownership regulations between industries with and without policy interventions. We also assume that there are no policy changes until a formal revision is announced in the published Catalogue.

For the measurement of contract environment, we follow the literature on the influence of institutional quality on the trade pattern (Nunn, 2007; Levchenko, 2007; Feenstra et al., 2010). These studies use the indexes of doing business in 30 provincial capitals in China published by the World Bank (2008). Specifically, we use a "court cost" variable, which is measured as the ratio of official costs of going through court procedures to the debt claim. Higher "court cost" indicates an inefficient, rent-seeking legal system, implying a lower probability of upholding contracts between firms. For convenience of interpretation, we construct a court efficiency measure, which equals 0.5 minus the ratio of court cost, as in Feenstra et al. (2010). ${ }^{9}$ The spatial differences in court efficiency in China are substantial. The Southeast coastal provinces usually have higher levels of court efficiency than do interior and northern provinces. In sequential regression analysis, we demean the court efficiency for easy comparison between different specifications.

To approximate trade cost, we use the cumulative number of national policy zones that had been opened up to a year in a specific province. ${ }^{10}$ China began to establish special economic zones

\footnotetext{
${ }^{9}$ World Bank (2008) also provides two other measures of contract environment: "court time," which measures the time interval between the time the plaintiff files the lawsuit and the time of payment, and "court rank" of the court system in each provincial capital based on the measures of "court cost" and "court time." As Nathan Nunn points out in Feenstra et al. (2010), either a very short period of time or a very long period of time can be an indicator of inefficient legal system; as such, there is no monotonic relationship between court time and court efficiency. We also agree with this point; thus, we use the court cost as a measure of judicial efficiency in our study.

${ }^{10}$ The data source is China Development Zone Review Announcement Catalogue (NDRC, 2007). We adopt this measure of trade cost rather than tariff because of two reasons. First, all imports for processing export are duty-free in China, and outward export tariffs are difficult to compute, in the sense that prohibited tariff are not observable. Even if outward export tariffs are available at the product level, there is no variation across provinces. Second, the setup of national policy zones requires authorization from the central government, which can be arguably considered as an exogenous process beyond the control of provincial governments. Therefore, the endogeneity problem is not a major concern.
} 
for export in the early 1980 in coastal cities. Owing to their initial success, special zones were expanded into inland cities (Wang, 2010). These policy zones include Economic and Technological Development Zone, High-Tech Development Area, Bonded Area, Export Processing Zone, and other types. Multinational companies in these zones enjoy various advantages, including lowered corporate tax rate of 15 percent, duty free for imported inputs, no import quotas, low costs of land, and no property tax in the first five years. There are also additional benefits for foreign firms if they export most of their products. The data reveal two booming periods of policy zones: the first is 1990-1993 when the cumulative number of zones jumped from 18 to 130 , and the second is $1999-2003$ when the number increased from 139 to 196 . By 2006, a total of 221 policy zones had been established in China. Their existence has significantly reduced the costs of international trade.

\subsection{Empirical Specification}

We assess the role of institutions and policies as determinants of product varieties in processing exports. The dependent variable for analysis, $\ln \left(E M_{\text {irot }}\right)$, is the log value of the extensive margin of industry $i$ and organizational form $o$ in province $r$ and year $t$. The principle explanatory variables are (1) an indicator variable for organizational form (i.e., $D_{\text {irot }}=1$ for FDI export by wholly foreign owned enterprises, and $D_{\text {irot }}=0$ for outsourcing export by independent domestic firms); (2) two indices of policy reforms, i.e., $E P_{i t}$ for encouragement policy and $R P_{i t}$ for restriction

policy; (3) an index of court efficiency, which approximates the degree of contract enforcement or institutional quality $\left(Q_{r}\right)$; and (4) the cumulative number of national policy zones, a proxy for trade cost $\left(T C_{r t}\right)$. The basic estimation equation is

$$
\begin{aligned}
\ln \left(E M_{\text {irot }}\right)= & \alpha_{1} D_{\text {irot }}+\alpha_{2} E P_{i t}+\alpha_{3} R P_{i t}+\alpha_{4} Q_{r}+\alpha_{5} T C_{r t} \\
& +\beta_{1} E R_{i t} D_{\text {irot }}+\beta_{2} R P_{i t} D_{\text {irot }}+\beta_{3} Q_{r} D_{\text {irot }}+\beta_{4} T C_{r t} D_{\text {irot }} \\
& +\sum_{m} \gamma_{m} G_{m r}+\gamma_{p} \ln \left(P D E N_{r t}\right)+\gamma_{y} \ln Y_{r t}+\sum_{n} \gamma_{n} V_{\text {irt }}+\delta_{i}+\delta_{t}+\epsilon_{\text {irot }} .
\end{aligned}
$$


This specification controls for a set of province-specific geographic variables $\left(G_{m r}\right)$, including the $\log$ value of minimum arc distance to two major ports in China (i.e., Shanghai and Hong Kong) and two indicator variables indicating whether a province has an international border and a coastal line, respectively. Accordingly, we do not use provincial dummies to control for regional fixed effects. We also add population density $\ln \left(P D E N_{r t}\right)$ and provincial real output $\ln Y_{r t}$ as controls for the market size effect that larger economies usually export more varieties (Krugman, 1979). Moreover, following Romalis (2004) and Nunn (2007), we also include the interaction $\left(V_{\text {nirt }}\right)$ of industry-specific factor intensities (i.e., skill intensity and capital intensity) and province-specific factor endowments (i.e., college share and capital output ratio) to capture the effects of locational comparative advantages. ${ }^{11}\left\{\delta_{i}, \delta_{t}\right\}$ are industry and yearly dummies, and $\epsilon_{\text {irot }}$ is a stochastic disturbance term. Note that the interaction terms between the organizational forms and policy variables allow us to test the differential effects of policy reforms on the export variety by FDI versus outsourcing.

To avoid the potential contemporaneous correlations between provincial variables with the error term, we use one-year lagged values of trade liberalization measures and those of factor endowment as the benchmark specification. ${ }^{12}$ In addition, as Lu et al. (2008) and Feenstra et al. (2010) point out, the contract environment variable $\left(Q_{r}\right)$ is likely to be endogenous to trade volume, as well as our measure of the extensive margin of processing export. We follow their practice of using former colonial rule, i.e., by British, France, Russia, Germany, Japan or a combination of multiple powers, as well as provincial population in 1953 as instruments for contract environment. Former colonials are expected to have poor contractual environments because of the extractive nature of the colonial influence; and, a larger population in a province in 1953 after the land reform implies

\footnotetext{
${ }^{11}$ The college share is defined as the proportion of college graduates in the population above age 5 (NBS, various years). The capital output ratio is defined as capital stock in real terms divided by the real GDP. We obtained the capital stock figures from Qian et al. (2007) and computed real GDP numbers based on China's Compendium of Statistics of 1949-2008 (NBS, 2009a). We rely on the 1995 Chinese National Industry Census (TNICO, 1997) to compute skill intensity by industry, which is defined as the share of workers with college education in total industrial employment, and industrial capital intensity, which is defined as the log ratio of net fixed capital over the total industrial employment.

${ }^{12}$ The changes in national polices on ownership regulations are arguably exogenous to industry and provincial variables because the progress of reforms depended largely on the decisions of the central government and the membership rules of the WTO regarding FDI investments. Our empirical analysis reveals that the main estimation results are not sensitive to alternative specifications of these variables.
} 
a predominant rural base in the past and thus the persistence of lower development in business and contractual environments. ${ }^{13}$ We will first estimate the above empirical function by OLS and then report the IV results using GMM. We will test for weak instruments using an F-test in the first-stage regression. The F-test statistics are all above the Stock-Yogo criteria of 10, rejecting the notion of weak instruments. Consequently, our discussions and interpretations of the results will be largely based on the IV estimates.

\subsection{Estimation Results}

The first two columns of Table 2 report the OLS and IV estimates of a simplified specification without the interaction of the indicator of foreign owned enterprises (FOE) and key policy variables. Therefore, these are regressions on the determinants of export varieties in the processing trade without distinguishing the differential effect of policies on export by FDI and outsourcing. Although these results do not provide direct tests on the implications of the model, several results emerge, and they remain stable across the alternative specifications.

First, the estimates for the FOE indicator variable are negative, showing that, on average, the extensive margin of processing export by foreign owned affiliates is less than that of the domestic independent firms. This result is not surprising because for many years the share of export through FDI was less than that through outsourcing. Second, the encouragement policy and special trade zones generally increase the extensive margin of processing exports, whereas the restriction policy presents a barrier to the growth of the extensive margin. Court efficiency does not have a significant effect on product variety. This result is consistent with the predictions of the model because improvements in contract enforcement have a neutral effect on processing export by independent domestic firms (Result 2). ${ }^{14}$ Third, the results of the geographic and market size variables are

\footnotetext{
${ }^{13}$ Please see the list of colonials in China after the Opium war in Feenstra et al. (2010). The estimated coefficients and their t-statistics for the colonial dummy and population variables are $-0.067(-10.11)$ and $-0.035(-9.93)$, respectively, in the first-stage of the estimation for our benchmark results. Interestingly, the negative correlation between former colonial experience and lower court efficiency in modern times is consistent with the main findings of Acemoglo et al. (2009) that the extractive states of the colonial past tend to leave negative influence on property rights and contractual development in China. These results are also robust if we exclude the colonials of Russian and Japan.

${ }^{14}$ Admittedly, the positive correlation between court efficiency and the coastal indicator may reduce the statistical
} 
consistent with the existing literature. The further away a region is from the two major ports, the fewer the variety of its export. Coastal provinces have more export varieties than do interior provinces, but having a land-connected international border does not increase variety for Chinese provinces. The significantly positive coefficients for population density and real output imply that the larger economy export more varieties. The positive coefficients of the interaction terms of skill intensity and college share, and those of capital intensity and capital output ratio suggest that skill (capital)-abundant regions export more varieties in skill (capital)-intensive industries.

The results from estimating the baseline equation are reported in columns (3) and (4), which lend support to the model's predictions. These specifications include the interactions of organizational form $\left(D_{\text {irot }}\right)$ and other key variables of policies and trade cost. Therefore, they can provide evidence on whether our variables of interest have differential effects on product variety across firm organizational forms. Based on the IV estimates, the encouragement policy raises the extensive margins of exports by independent firms and foreign owned firms by $\exp (0.244)-1=28$ percent and $\exp (0.244+0.146)-1=48$ percent, respectively, compared with those in industries without such policy. This finding is consistent with Result 1, i.e., the relaxation of ownership restrictions strongly increases the export varieties through vertical integrated firms. Perhaps an unexpected result is that the extensive margin of outsourcing export also increases, which goes beyond the prediction of the model. However, this result is hardly surprising because the industries targeted by the government encouragement policies are also likely to receive other preferential treatments, have reduced bureaucratic barriers, and encounter lower entry costs for all types of firms, thus leading to expansion in the processing trade by indigenous Chinese firms and joint ventures. As a result of ownership liberalization, positive productivity spillover to Chinese firms by the growing presence of multinational companies may also promote new product development. In contrast to ownership liberalization, the restriction policy significantly reduces export variety through FDI by $1-\exp (-0.215)=19$ percent, whereas it has an insignificant effect on the export

significance of the coefficient on court efficiency. Nevertheless we still include both variables in the regression because an alternative specification of removing the coastal indicator may lead to omitted variable bias because coastal areas usually have higher trade volume and more export varieties. 
variety by outsourcing.

The IV estimates in column (4) also provide strong empirical support to Result 2. The large coefficient for the interaction of FOE and court efficiency suggests that contract enforcement has a significantly positive effect on the export variety of vertically integrated foreign affiliates. Consistent with the model's prediction, contract environment does not significantly affect the variety of outsourcing export because improvements in contract enforcement do not alter the cutoff point between foreign affiliates and Southern independent firms (Figure 2). Overall, the effect of institutional quality on the product variety of FDI export is large. Consider the inland province of Sichuan, which has a court efficiency index of 8.99 percent, and the coastal city of Shanghai, which has an index value at 26.65 percent. The estimated coefficients imply that, if Sichuan had the same efficient court system as Shanghai, ceteris paribus, the export variety by FOE would increase by 32 percent $(=\exp (1.607 *(26.65 \%-8.99 \%))-1)$.

Our model highlights an amplification effect from the coordination of reforms. The main idea is that one institutional reform may have a larger effect the better the other institution. For instance, improvement in contract enforcement may have a stronger effect on export variety as ownership restriction is removed. To test the implications of Result 3, we present the estimation results of triple interactions of organizational form, ownership policies, and contract environment variables in columns (5) and (6) of Table 2, together with double interactions of two policies. The coefficient of the double interaction of FOE-encouragement policy turns positive and this implies that at the average level of contract environment, the encouragement policy has positive effect on the product variety of FDI export. Moreover, the triple interaction term of FOE-encouragement policy-court efficiency is large and significantly positive, indicating strong complementarity between ownership liberalization and contract environment for foreign owned affiliates. To illustrate the size of the amplifying effect, consider two coastal provinces, Shandong and Fujian provinces. In terms of contract efficiency, Shandong is at the median, whereas Fujian is ranked at the top 25 percentile. With lower court efficiency in Shandong, having encouragement policy would increase its FDI export variety by 48 percent $(=\exp (0.226+0.307+(-1.297+5.138) *(0.28-0.317))-1)$, 
whereas with higher court efficiency in Fujian, the same policy reform would raise its export variety by a much higher 101 percent $(=\exp (0.226+0.307+(-1.297+5.138) *(0.36-0.317))-1)$, both relative to industries without the encouragement policy. Therefore, differences in contract environment may lead to significantly different outcomes under the same reform scheme. This result has important policy implications, suggesting that well-coordinated reforms are crucial for expanding product varieties for developing countries. More strikingly, the double interaction of encouragement policy-court efficiency has a negative significant coefficient, which implies that ownership liberalization reduces more export varieties for independent domestic firms in provinces with better contract environment.

Our empirical results also shed lights on the debate on the boundaries of multinational firms. An earlier literature based on transaction-cost theories emphasizes the difficulty of enforcing intellectual property rights in host countries (Markusen, 1995). These studies predict that multinationals prefer vertical integration to protect their technology secrets, particularly in countries with poor contract environments. However, we find the opposite evidence, which is consistent with a more recent literature based on property-rights theories of the firm (Antràs and Helpman, 2008; Antràs, 2012). As discussed in Result 2, this approach predicts that multinationals with a wider range of headquarter intensity prefer vertical integration in regions with better contract environments. Therefore, ownership liberalization in host countries would lead to higher growth of exports by wholly foreign-owned firms, particularly in better contracting environments. Our results provide evidence in support of property-rights theories of firm boundaries and generate useful policy implications for institutional reforms in developing countries.

The establishment of national policy zones also has significantly positive effects on product development in the processing trade. Based on the estimates in column (4), the opening of one additional policy zone in a province is associated with 12 percent and 8 percent increases in export varieties by FDI and outsourcing, respectively. Whereas the effect on the FDI export is consistent with Result 3, the effect of policy zones on export variety by outsourcing could stem from similar spillover effects or preferable policies related to the opening of special zones for all types of 
firms, as we discussed in the case of encouragement policy. In addition, we do not find significant amplification effect of trade cost reduction and ownership liberalization.

\subsection{Sensitivity Analysis}

In this section, we carry out robustness checks for our previous findings. Included in the exercise are alternative measures of the extensive margin, the log value of processing export as the dependent variable, and the use of high-income countries as the North in the regression analysis. We find that all the major results are robust to these alternative specifications.

First, we employ two alternative measures of the extensive margin. The first is a straightforward count of product varieties, in which variety is still defined as the eight-digit HS product-country pair. The second measure is a redefined variety by an eight-digit HS product, but it is still computed as FK index. The number of varieties is reduced because of the broader scope of the definition. Table 3 presents the IV regression results based on these two alternative measures. The results are highly consistent with our benchmark findings, especially in the interaction terms with FOE, reconfirming the fact that the effects of host country reforms on product variety are not sensitive to the use of different measures of the extensive margin. One noticeable difference is that the estimated coefficients for the encouragement policy in columns (2) and (3) in Table 3 have turned statistically insignificant from previously significantly positive numbers in columns (4) and (6) in Table 2. This finding lends direct support to our hypothesis in Result 1; i.e., ownership liberalization does not increase the extensive margin of export by independent firms. Another difference is that the estimated coefficients for the restriction policy in columns (2) and (3) have turned statistically significant positive numbers from insignificant estimates in columns (4) and (6) in Table 2. This result does not go against our theoretical predictions either. It simply implies that ownership controls on foreign ownership may actually increase the export variety of arm's length arrangement because of reduced foreign competition. These two estimation differences suggest that using the number of export variety as the dependent variable may bring additional evidence in support of the theoretical predictions. 
Another interpretation of these above differences in estimation results is caused by the weighting schemes in the two measures of the extensive margin. The mechanical count of product variety does not consider the export volume of each product. However, FK index is a weighted number of products, in which the weights are the average export value over the sample period. Therefore, it makes sense if the encouragement (restriction) policy increases (deceases) the export value in these preferred industries, as shown in Table 2.

Second, Table 4 presents the IV regression results when the dependent variable is the log export value. The results are again broadly consistent with our benchmark estimation. One noticeable finding is that the amplification effect of court efficiency on FDI export in the encouraged industry becomes even larger. Taking the same cases of Shandong and Fujian as examples, the encouragement policy now increases the FDI export by 39 percent and 100 percent in the two provinces, respectively, relative to those industries without an encouragement policy.

Lastly, instead of using all other countries as the North, we select all high-income countries as the North. Our definition of high-income countries follows the World Bank's standard classification; China's export to high-income countries accounts for about 89 percent of the total processing export. ${ }^{15}$ Table 5 presents the estimation results based on the high-income country sample using both the FK extensive margin index and export value as dependent variables. Again, all results are broadly consistent with our benchmark findings.

\section{Concluding Remarks}

In this paper, we study the effects of host country policy reforms on the decisions of multinational companies to offshore their productions to developing countries. We incorporate the liberalization of FDI ownership and improvement in contract environment into a model of global sourcing, which features vertical integration and arm's length transaction. Our model suggests that, while ownership liberalization has a direct positive effect on expanding product variety in the

\footnotetext{
${ }^{15}$ Taiwan is not included in the World Bank's data, although it qualifies for a high-income region. We add Taiwan into our sample because it is an important trade partner of mainland China.
} 
South, a simultaneous reform of raising judicial efficiency can achieve a large, amplifying effect. Based on the recent Chinese experience, our empirical findings have provided strong support for the theoretical prediction that policy reforms can expand export variety.

Governments in developing countries aspire to attract direct investment by multinational companies with new products and advanced technologies. However, their strategies vary. Some governments prohibit wholly-owned foreign subsidiaries from entering the local markets; rather, they encourage the establishment of joint-ventures while imposing technology-sharing mandates. Our research suggests that these policies may lead to undesired outcomes. The reason is that, under stringent ownership restrictions, multinational companies will find it unattractive to set up their subsidiaries in the South and bring in advanced products. Instead, they will only transfer less advanced products to the South through arm's length transactions. In contrast, if the host country governments choose to liberalize their ownership structures with concurrent improvements in contract enforcement, they will attract the transfer of more advanced products by multinationals. This expanded product varieties will in turn contribute to economic growth and welfare in developing countries.

\section{References}

Acemoglu, D., Johnson, S., Mitton, T., 2009. Determinants of vertical integration: Financial development and contracting costs. Journal of Finance 64 (3), 1251-1290.

Antràs, P., 2005. Incomplete contracts and the product cycle. American Economic Review 95 (4), 1054-1073.

Antràs, P., 2012. Grossman-Hart (1986) Goes Global: Incomplete Contracts, Property Rights, and the International Organization of Production. Journal of Law, Economics and Organization, forthcoming.

Antràs, P., Helpman, E., 2008. Contractual frictions and global sourcing. In: Helpman, E., D. 
Marin and T. Verdier (Ed.), The Organization of Firms in a Global Economy. Harvard University Press, pp. 9-54.

Basco, S., 2010. Financial development and the product cycle. Universidad Carlos III, working paper.

Blonigen, B., Ma, A., 2010. Please pass the catch-up: The relative performance of Chinese and foreign firms in Chinese exports. In: Feenstra, R. C., Wei, S.-J. (Eds.), China's Growing Role in World Trade. University of Chicago Press, pp. 475 - 509.

Branstetter, L., Lardy, N., 2008. China's embrace of globalization. In: Brandt, L., Rawski, T. (Eds.), Chinas Economic Transition: Origins, Mechanisms, and Consequences. Cambridge University Press, pp. 633-682.

Broda, C., Weinstein, D. E., 2006. Globalization and the gains from variety. Quarterly Journal of Economics 121 (2), 541-585.

Chin, J. C., Grossman, G. M., 1990. Intellectual property rights and North-South trade. In: Jones, R., Krueger, A. O. (Eds.), The Political Economy of International Trade. Oxford: Basil Blackwell, pp. 90-107.

Debaere, P., Mostashari, S., 2010. Do tariffs matter for the extensive margin of international trade? An empirical analysis. Journal of International Economics 81 (2), 163-169.

Diwan, I., Rodrik, D., 1991. Patents, appropriate technology, and North-South trade. Journal of International Economics 30 (1-2), 27-47.

Eaton, J., Kortum, S., 2002. Technology, geography, and trade. Econometrica 70 (5), 1741-1779.

Feenstra, R., Hanson, G., 2005. Ownership and control in outsourcing to China: Estimating the property-rights theory of the firm. Quarterly Journal of Economics 120 (2), 729-761.

Feenstra, R., Hong, C., Ma, H., Spencer, B., 2010. Contractual versus non-contractual trade: The role of institutions in China. University of California, Davis, working paper. 
Feenstra, R., Kee, H., 2008. Export variety and country productivity: Estimating the monopolistic competition model with endogenous productivity. Journal of International Economics 74 (2), 500-518.

Gastanaga, V., Nugent, J., Pashamova, B., 1998. Host country reforms and FDI inflows: How much difference do they make? World Development 26 (7), 1299-1314.

Glass, A., Saggi, K., 1998. International technology transfer and the technology gap. Journal of Development Economics 55 (2), 369-398.

Goldberg, P., Khandelwal, A., Pavcnik, N., Topalova, P., 2010. Imported intermediate inputs and domestic product growth: Evidence from India. Quarterly Journal of Economics 125 (4), 17271767.

Gomes-Casseres, B., 1990. Firm ownership preferences and host government restrictions: An integrated approach. Journal of International Business Studies 21 (1), 1-22.

Grossman, G., Helpman, E., 1991. Endogenous product cycles. Economic Journal 101 (408), $1214-1229$.

Grossman, S. J., Hart, O. D., 1986. The costs and benefits of ownership: A theory of vertical and lateral integration. Journal of Political Economy 94 (4), 691-719.

Hausmann, R., Hwang, J., Rodrik, D., 2007. What you export matters. Journal of Economic Growth $12(1), 1-25$.

Hummels, D., Klenow, P., 2005. The variety and quality of a nation's exports. American Economic Review, 704-723.

Kobrin, S., 1987. Testing the bargaining hypothesis in the manufacturing sector in developing countries. International Organization 41 (4), 609-638.

Krugman, P., 1979. Increasing returns, monopolistic competition, and international trade. Journal of International Economics 9 (4), 469 - 479. 
Krugman, P. R., 1981. Intraindustry specialization and the gains from trade. Journal of Political Economy 89 (5), pp. 959-973.

Levchenko, A., 2007. Institutional quality and international trade. Review of Economic Studies 74 (3), 791-819.

Lu, Y., Png, I., Tao, Z., 2008. Do institutions not matter in China? Evidence from enterprise-level productivity growth. University of Hong Kong, working paper.

Markusen, J., 1995. The boundaries of multinational enterprises and the theory of international trade. Journal of Economic Perspectives 9 (2), 169-189.

Melitz, M., 2003. The impact of trade on aggregate industry productivity and intra-industry reallocations. Econometrica 71 (6), 1695-1725.

National Bureau of Statistics of China (NBS), 1997-2007. China Population Statistics Yearbook. China Statistics Press, Beijing.

National Bureau of Statistics of China (NBS), 2005. Product Classification for Statistics (Temporary Version). China Statistics Press, Beijing.

National Bureau of Statistics of China (NBS), 2009a. China Compendium of Statistics 1949-2008. China Statistics Press, Beijing.

National Bureau of Statistics of China (NBS), 2009b. China Trade and External Economic Statistical Yearbook. China Statistics Press, Beijing.

National Development and Reform Commission (NDRC), 1995. The catalogue for the guidance of foreign investment industries. Revisions of 1997, 2002, 2004 and 2007.

National Development and Reform Commission (NDRC), 2007. China development zone review announcement catalogue. 
Nunn, N., 2007. Relationship-specificity, incomplete contracts, and the pattern of trade. Quarterly Journal of Economics 122 (2), 569-600.

Qian, Y., Bai, C., Hsieh, C., 2007. The return to capital in China. Brookings Papers on Economic Activity 2006 (2), 61-101.

Romalis, J., 2004. Factor proportions and the structure of commodity trade. American Economic Review 94 (1), 67-97.

TNICO, The Third National Industrial Census Office, 1997. The Data of the Third Industrial Census of the People's Republic of China in 1995, Industrial Volume. China Statistics Press, Beijing.

Wang, J., 2010. The economic impact of special economic zones: Evidence from Chinese municipalities. Hong Kong University of Science and Technology, working paper.

Wei, S., 2000. How taxing is corruption on international investors? Review of Economics and Statistics $82(1), 1-11$.

World Bank, 2008. Doing Business in China. Available at: www.doingbusiness.org/china. 


\section{Appendix A: Proof of Lemma 1}

We first derive the properties of $B^{O}(z)$ for $O \in\{A, V\}$. Consider the case in which the producer chooses an independent Southern firm to produce the intermediate input. With $\beta=1 / 2$, we have

$$
B^{A}(z)=\left[\phi+(1-\phi) \frac{1-1 / 2 \alpha}{1-\alpha}(1 / 2)^{\alpha /(1-\alpha)}\right]^{-\frac{1-\alpha}{\alpha z}}
$$

It is easy to show that $B^{A}(z)$ has the following proposition:

\section{Proposition 1}

(1) $B^{A}(1)>1, \lim _{z \rightarrow 0} B^{A}(z)=\infty, B_{z}^{A}(z)<0$, and $B_{\phi}^{A}(z)<0$.

(2) If $B^{A}(1)<\omega / \tau$, there exists a unique cutoff $\bar{z}_{N A}$, such that $B^{A}\left(\bar{z}_{N A}\right)=\omega / \tau$, and $B^{A}(z)>$ $\omega / \tau$ if $z<\bar{z}_{N A}$, and $B^{A}(z)<\omega / \tau$ if $z>\bar{z}_{N A}$.

Given $\alpha \in(0,1), f(x)=(1-\alpha x) x^{\frac{\alpha}{1-\alpha}}$ is an increasing function for $x \in[0,1]$, thus $\frac{1-1 / 2 \alpha}{1-\alpha}(1 / 2)^{\alpha /(1-\alpha)}<1$, and the term in the bracket of $B^{A}(z)$ is less than 1 . Therefore, it is easy to show $B^{A}(1)>1, \lim _{z \rightarrow 0} B^{A}(z)=\infty$, and $B_{z}^{A}(z)<0$ and $B_{\phi}^{A}(z)<0$. As shown in Figure $1, B^{A}(z)$ decreases in $z$. Thus, if $B^{A}(1)<\omega / \tau$, then there exists a unique cutoff $\bar{z}_{N A}$, such that $B^{A}\left(\bar{z}_{N A}\right)=\omega / \tau, B^{A}(z)>\omega / \tau$ if $z<\bar{z}_{N A}$, and $B^{A}(z)<\omega / \tau$ if $z>\bar{z}_{N A}$.

We can show that with the same assumptions in Antras(2005), the $B^{V}(z)$ curve has similar properties:

\section{Proposition 2}

(1) $B^{V}(1)>B^{A}(1), \lim _{z \rightarrow 0} B^{V}(z)=\infty$, and $B_{\phi}^{V}(z)<0$.

(2) If $\delta^{\alpha}<1 / 2$, i.e., $\beta^{V}<3 / 4$, then $B_{z}^{V}(z)<0$.

(3) If $B^{V}(1)<\omega / \tau$, there exists a unique cutoff $\bar{z}_{N V}$, such that $B^{V}\left(\bar{z}_{N V}\right)=\omega / \tau, B^{V}(z)>\omega / \tau$ if $z<\bar{z}_{N V}$, and $B^{V}(z)<\omega / \tau$ if $z>\bar{z}_{N V}$. 
(4) There exists a unique cutoff $\bar{z}_{A V}$, such that $B^{A}\left(\bar{z}_{A V}\right)=B^{V}\left(\bar{z}_{A V}\right), B^{A}(z)>B^{V}(z)$ if $z<$ $\bar{z}_{A V}$, and $B^{A}(z)<B^{V}(z)$ if $z>\bar{z}_{A V}$. Moreover, this cutoff $\bar{z}_{A V}$ is independent of $\phi$.

We know

$$
B^{V}(z)=\left[\phi+(1-\phi) \frac{1-\alpha \beta^{V}(1-z)-\alpha\left(1-\beta^{V}\right) z}{1-\alpha}\left[\left(\beta^{V}\right)^{1-z}\left(1-\beta^{V}\right)^{z}\right]^{\alpha /(1-\alpha)}\right]^{-\frac{1-\alpha}{\alpha z}}
$$

Hence, $B^{V}(1)=\left[\phi+(1-\phi) \frac{1-\alpha\left(1-\beta^{V}\right)}{1-\alpha}\left(1-\beta^{V}\right)^{\alpha /(1-\alpha)}\right]^{-\frac{1-\alpha}{\alpha}}$, and given the property of $f(x)$ and $\beta^{V} \in(1 / 2,1)$, we know $0<f\left(1-\beta^{V}\right)<f(1 / 2)$. Then, $\phi+(1-\phi) f\left(1-\beta^{V}\right)<$ $\phi+(1-\phi) f(1 / 2)$, and thus $B^{V}(1)>B^{A}(1)$.

Next, define $\Phi(z, \beta) \equiv \frac{1-\alpha[\beta(1-z)+(1-\beta) z]}{1-\alpha}\left[\beta^{1-z}(1-\beta)^{z}\right]^{\alpha /(1-\alpha)}$, which is less than 1 , as shown in Appendix A of Antràs (2005). Therefore, $\phi+(1-\phi) \Phi(z, \beta)<1$, and a rising $\phi$ increases $(\phi+(1-\phi) \Phi(z, \beta))$ for a given $z$. Thus, $\lim _{z \rightarrow 0} B^{V}(z)=\infty$, and $B_{\phi}^{V}(z)<0$.

For proposition 2(2), if $\phi=0$, it reduces to the case in Antras (2005). Antras shows that $\delta^{\alpha}<1 / 2$ is the sufficient condition for $B_{z}^{V}(z)<0$. It is difficult to provide a close-form proof for the general case $\phi \in(0,1)$, given the complex form of $B^{V}(z)$. However, Matlab random simulations for one million sets of parameter values of $\alpha \in(0,1), \phi \in[0,1], \beta^{V} \in(0.5,0.75)$ for 99 grids of $z \in[0.01,0.99]$ suggest that the inequality holds for every simulation. Secondly, we choose 0.01 as the grid for each parameter, and verify that the inequality still hold for every combination of parameters in the grid space. Based on these numerical exercises, we believe that the likelihood of multiple equilibria is extremely small. This is reasonable because as $\phi$ increases from 0 to 1 , the severity of contract incompleteness declines.

Given the propositions 2(1) and 2(2), and if $B^{V}(1)<\omega / \tau$, then there exists a unique cutoff $\bar{z}_{N V}$, such that $B^{V}\left(\bar{z}_{N V}\right)=\omega / \tau, B^{V}(z)>\omega / \tau$ if $z<\bar{z}_{N V}$, and $B^{V}(z)<\omega / \tau$ if $z>\bar{z}_{N V}$.

To derive proposition 2(4), we only need to compare $\Phi\left(z, \beta^{V}\right)$ and $\Phi\left(z, \beta^{A}\right)$. Let

$$
\Gamma(z)=\Phi\left(z, \beta^{V}\right) / \Phi\left(z, \beta^{A}\right)=\frac{1-\alpha\left[\left(\beta^{V}\right)(1-z)+\left(1-\beta^{V}\right) z\right]}{1-\alpha / 2}\left[2\left(\beta^{V}\right)^{1-z}\left(1-\beta^{V}\right)^{z}\right]^{\alpha /(1-\alpha)}
$$


First, to demonstrate $\Gamma(z)$ decreases in $z$, we only need to show

$$
\frac{\alpha}{1-\alpha} \ln \frac{\beta^{V}}{1-\beta^{V}}>\frac{\alpha\left(2 \beta^{V}-1\right)}{1-\alpha \beta^{V}-\alpha\left(1-2 \beta^{V}\right) z} .
$$

As the RHS decreases in $z$, it is no larger than $\frac{\alpha\left(2 \beta^{V}-1\right)}{1-\alpha \beta^{V}}$, which is less than the LHS. To show this, define $G(\beta)=\frac{\alpha}{1-\alpha} \ln \frac{\beta^{V}}{1-\beta^{V}}-\frac{\alpha\left(2 \beta^{V}-1\right)}{1-\alpha \beta^{V}}$. It is easy to show $G\left(\beta^{V}\right)$ is increasing in $\beta^{V}$; thus, $G\left(\beta^{V}\right)>G(1 / 2)=0$.

Moreover, $\Gamma(0)=\frac{1-\alpha \beta^{V}}{1-\alpha / 2}\left[2 \beta^{V}\right]^{\alpha /(1-\alpha)}$ and $\Gamma(1)=\frac{1-\alpha\left(1-\beta^{V}\right)}{1-\alpha / 2}\left[2\left(1-\beta^{V}\right)\right]^{\alpha /(1-\alpha)}$. Given $\alpha \in$ $(0,1), g(x)=\frac{1-\alpha x}{1-\alpha / 2}[2 x]^{\alpha /(1-\alpha)}$ increases in $x$ for $x \in(0,1)$. Hence, $\beta^{V}>1 / 2$ implies that $g\left(1-\beta^{V}\right)<g(1 / 2)=1<g\left(\beta^{V}\right)$, which give the result $\Gamma(1)<1<\Gamma(0)$. Therefore, there exists a unique cutoff $\bar{z}_{A V}$, such that $B^{A}\left(\bar{z}_{A V}\right)=B^{V}\left(\bar{z}_{A V}\right), B^{A}(z)>B^{V}(z)$ if $z<\bar{z}_{A V}$, and $B^{A}(z)<B^{V}(z)$ if $z>\bar{z}_{A V}$. Moreover, because $\Phi\left(z, \beta^{V}\right)$ and $\Phi\left(z, \beta^{A}\right)$ are independent of $\phi$, the cutoff $\bar{z}_{A V}$ is also independent of $\phi$.

Proposition 3 If $\bar{z}_{N V}<\bar{z}_{N A}<\bar{z}_{A V}$, then the Lemma 1 holds.

Based on propositions 1(2) and 2(3), we know the intermediate input is produced in the North if $z<\min \left\{\bar{z}_{N A}, \bar{z}_{N V}\right\}$. Moreover, it is easy to verify that three cutoffs must satisfy one of the following order: (1) $\bar{z}_{A V}=\bar{z}_{N A}=\bar{z}_{N V}$, (2) $\bar{z}_{A V}<\bar{z}_{N A}<\bar{z}_{N V}$, and (3) $\bar{z}_{N V}<\bar{z}_{N A}<\bar{z}_{A V}$. The first case has small likelihood to happen, and in the second case, the vertical integration will be dominated by the choice of Northern production and arm's length production in the South. This case is not interesting for our empirical purpose. For the third case, for $z<\bar{z}_{N V}$, its intermediate input is produced in the North. For $\bar{z}_{N V}<z<\bar{z}_{A V}$, its intermediate input is produced by foreign integrated firms in the South. And, for $z>\bar{z}_{A V}$, its intermediate input is produced by independent firms in the South. Thus, the lemma 1 holds. 


\section{Appendix B: General Equilibrium Effects}

We show that the main results derived from our partial equilibrium analysis remain valid in general equilibrium with free entry. The main difference is that the growth in the extensive margin due to policy changes in general equilibrium will be reduced because the relative wage in the South increases due to rising labor demand as more production is offshored from the North.

The preference of the representative consumer in each country is given by

$$
U=\int_{0}^{N} \log \left(\int_{0}^{n_{j}} y^{\alpha}(i) d i\right)^{1 / \alpha} d j
$$

where $y_{j}(i)$ is total consumption of brand $i$ of product $j$ (e.g., the iphone of cell phones), and $N$ is the measure of total products. This setup implies different brands of the same product have the same factor intensity. For simplicity, we assume each firm produces one brand of some product.

Given this preference, we can show that the demand shifter for each product is given by

$$
\lambda_{j}=\frac{E}{N \int_{0}^{n_{j}} p_{j}\left(i^{\prime}\right)^{-\frac{\alpha}{1-\alpha}} d i^{\prime}} .
$$

Entrants could pay a fixed cost of $f$ units of labor in the North, and free entry implies that the measure $n_{j}$ of variety for each good always adjusts so as to make Northern final-good producers break even. We can show that

$$
n_{j}= \begin{cases}\frac{(1-\alpha) E}{N f w^{N}} & z \in \Omega^{N} \equiv\left[0, \bar{z}_{N V}\right) \\ \frac{E}{N f w^{N}} \frac{\phi(1-\alpha)+(1-\phi)\left[1-\alpha \beta^{V}(1-z)-\alpha\left(1-\beta^{V}\right) z\right] \Delta^{V}}{\phi+(1-\phi) \Delta^{V}} & z \in \Omega^{S V} \equiv\left[\bar{z}_{N V}, \bar{z}_{A V}\right) \\ \frac{E}{N f w^{N}} \frac{\phi(1-\alpha)+(1-\phi)\left[1-\alpha \beta^{A}(1-z)-\alpha\left(1-\beta^{A}\right) z\right] \Delta^{A}}{\phi+(1-\phi) \Delta^{A}} & z \in \Omega^{S A} \equiv\left[\bar{z}_{A V}, 1\right]\end{cases}
$$

where $\Delta^{O}=\left[\left(\beta^{O}\right)^{(1-z)}\left(1-\beta^{O}\right)^{z}\right]^{\alpha /(1-\alpha)}$, and $O=V$, $A$. We can also show $n_{j, z \in \Omega^{S O}}>n_{j, z \in \Omega^{N}}$, implying that the number of varieties for every product in the South is larger than that of each product in the North. Because of incomplete contract in the South, multinationals who offshore will charge higher prices and sell less outputs, thus each firm captures smaller market shares, 
and this in turn induces more entry. Moreover, we can show $n_{j, z \in \Omega^{S O}}$ decreases in $\phi$, i.e., as contract environment in the South improves, the number of varieties for each product in the South declines. ${ }^{16}$ The intuition is similar. As the contract friction declines, each firm's market share increases, thus resulting in less entry. As such, improvements in contract environment have two effects on the product variety of FDI export. First, it induces more multinational firms with higher headquarter intensity to offshore their production to the South. Second, it reduces the number of brands for each product. Therefore, the total effect of improvement in contract environment depends on which of the two effects dominates.

Our study mainly focuses on the first effect because of two reasons. First, our data is reported at the product level rather than the firm level, which refrains us to explore the second effect. Second, the number of firms also depends on fixed costs of entry. If the entry cost declines, as expected for improvements in contract environment, the number of firms for each product will also increase.

Next we solve the general equilibrium. The world income is equal to world expenditure on all goods,

$$
w^{N} L^{N}+w^{S} L^{S}=E
$$

and the labor market clears in each country. According to Walras' law, we only need to clear one of the two labor markets and we choose to focus on the Southern labor market.

Without loss of generality, we show the case in which only outsourcing to the South is possible. The case is sufficient for us to see the general equilibrium effect.

If we denote $F(z)$ as the fraction of products with $z<z^{*}$ and $f(z)$ as its density function, the labor market clearing condition in the South implies that

$$
w^{S} L^{S}=\frac{\alpha E}{\tau} \int_{\bar{z}}^{1} z r(\phi) f(z) d z
$$

where $\bar{z}$ is the cutoff between Southern and Northern production, and $r(\phi)=\frac{\left(1-\beta^{A}\right)(1-\phi) \Delta^{A}+\phi}{(1-\phi) \Delta^{A}+\phi} \in$

\footnotetext{
${ }^{16}$ This conclusion is conditional on the constant expenditure $E$ and relative wages. As we show below, the total expenditure and relative wages will also change as the contract environment improves in the general equilibrium model. In this case, the improvement in contracting has an ambiguous effect on the number of varieties.
} 
$(0,1)$. Combining Equations (.6) and (.7), we get

$$
\omega=G(\bar{z})=\frac{1-\frac{\alpha}{\tau} \int_{\bar{z}}^{1} z r(\phi) f(z) d z}{\frac{\alpha}{\tau} \int_{\bar{z}}^{1} z r(\phi) f(z) d z} \frac{L^{S}}{L^{N}}
$$

$G(z)$ is an increasing function of $\bar{z}$ satisfying $G(0)>0$ and $\lim _{\bar{z} \rightarrow 1} G(\bar{z})=+\infty$. Intuitively, the higher is $\bar{z}$, the lower labor demand in the South; hence, an increase in relative wage $\omega$ is necessary to bring the Southern labor market back to equilibrium.

Another condition to pin down $\omega$ and $\bar{z}$ is given in the partial equilibrium, $\omega=\tau B^{A}(\bar{z})$. Figure 5 plots $G(z) / \tau$ and $B^{A}(z)$. The intersection of two curves pins down the equilibrium effective relative wage $\omega^{*} / \tau$ and the cutoff $\bar{z}$. Also, because $B^{A}(1)>1$, then $\omega^{*} / \tau>1$. Under this setting, all our analyses in Results 1-4 could be rechecked easily in the general equilibrium framework, just by replacing the horizontal line $\omega / \tau$ with the upward sloping curve $G(z) / \tau$.

For instance, an improvement in contract environment shifts down the $B^{A}(z)$ curve. In partial equilibrium, the effective relative wage is fixed and thus all products $z>\bar{z}_{N A}^{P E}$ are offshored to the South, wheras in general equilibrium, those offshoring tasks raise the demand for Southern labor and lower the effective relative wage, thus only products $z>\bar{z}_{N A}^{G E}$ are offshored. In other words, the positive effect of contractual improvement on product variety will be reduced in general equilibrium. Similarly, the effect of trade cost reduction on product variety will be smaller in general equilibrium than in partial equilibrium. When vertical integration is allowed, we need to redefine $G(\bar{z}) / \tau$ by including two organizational forms, and use $\min \left\{B^{V}(z), B^{A}(z)\right\}$ to replace $B^{A}(z)$. Again, the effect of ownership liberalization on product variety will be smaller in the general equilibrium framework.

In summary, our predictions of ownership liberalization, improvement in contract environment and trade cost reduction still hold in general equilibrium with free entry, but their effects on export variety will be smaller than in partial equilibrium. However, the general equilibrium effect from rising relative wages will be limited if we consider a small open economy or a country like China where there is abundant supply of cheap labor. 
Table 1: Summary Statistics of China's Processing Export

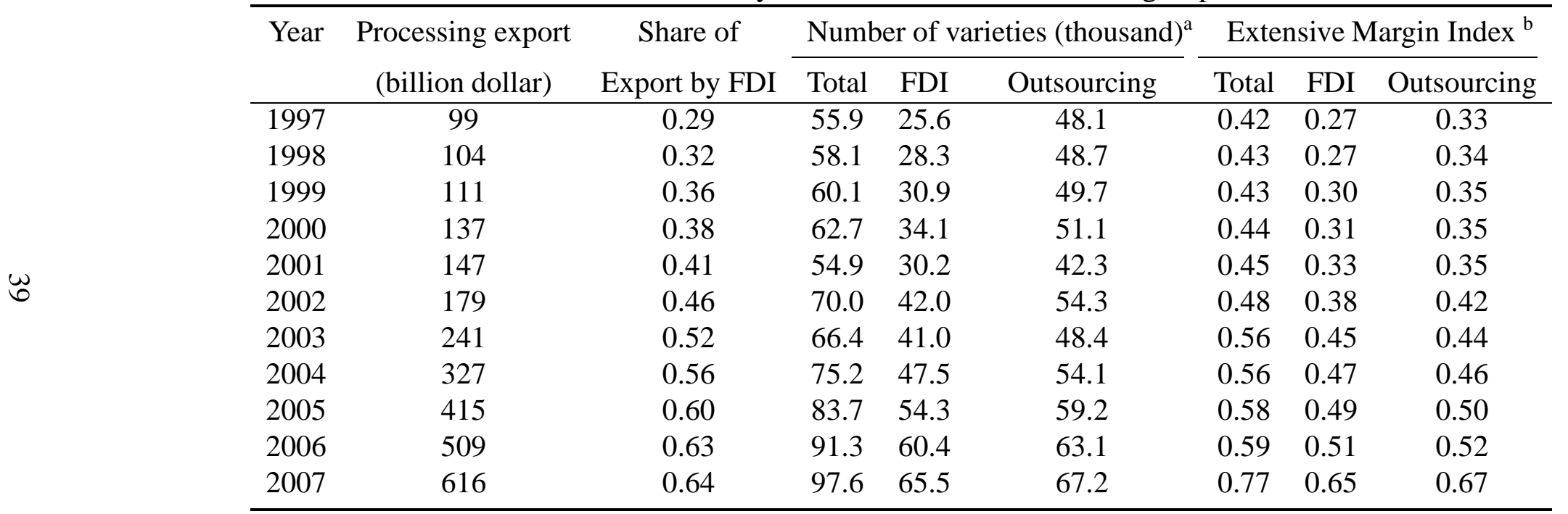

${ }^{a}$ Variety is defined as an eight-digit HS product-destination country pair. Note that the total number of varieties is not equal to the sum of the varieties by intrafirm and arm's length export because different firms can export the same variety.

b This index of extensive margin is based on Feenstra and Kee (2008), as explained in Equation (5). 
Table 2: Determinants of the Extensive Margin in Processing Export

\begin{tabular}{|c|c|c|c|c|c|c|}
\hline \multirow[b]{2}{*}{ Independent variable } & \multicolumn{6}{|c|}{ Dependent variable: $\log ($ Extensive Margin Index $)$} \\
\hline & $\begin{array}{l}\text { OLS } \\
\text { (1) }\end{array}$ & $\begin{array}{l}\text { IV } \\
(2)\end{array}$ & $\begin{array}{l}\text { OLS } \\
(3)\end{array}$ & $\begin{array}{l}\text { IV } \\
(4)\end{array}$ & $\begin{array}{l}\text { OLS } \\
(5)\end{array}$ & $\begin{array}{l}\text { IV } \\
(6)\end{array}$ \\
\hline FOE indicator & $\begin{array}{c}-0.461 * * * \\
(0.035)\end{array}$ & $\begin{array}{c}-0.488^{* * *} \\
(0.035)\end{array}$ & $\begin{array}{c}-0.862 * * * \\
(0.073)\end{array}$ & $\begin{array}{c}-0.881 * * * \\
(0.075)\end{array}$ & $\begin{array}{c}-0.815 * * * \\
(0.075)\end{array}$ & $\begin{array}{c}-0.879 * * * \\
(0.074)\end{array}$ \\
\hline Encouragement policy & $\begin{array}{c}0.305^{* * * *} \\
(0.059)\end{array}$ & $\begin{array}{c}0.301 * * * \\
(0.059)\end{array}$ & $\begin{array}{c}0.235 * * * \\
(0.063)\end{array}$ & $\begin{array}{c}0.244 * * * \\
(0.062)\end{array}$ & $\begin{array}{l}0.191 * * \\
(0.076)\end{array}$ & $\begin{array}{c}0.226 * * * \\
(0.080)\end{array}$ \\
\hline Restriction policy & $\begin{array}{c}-0.166 * * * \\
(0.050)\end{array}$ & $\begin{array}{c}-0.157 * * * \\
(0.051)\end{array}$ & $\begin{array}{l}-0.057 \\
(0.055)\end{array}$ & $\begin{array}{l}-0.057 \\
(0.055)\end{array}$ & $\begin{array}{l}-0.025 \\
(0.073)\end{array}$ & $\begin{array}{l}-0.154 * \\
(0.081)\end{array}$ \\
\hline Court efficiency & $\begin{array}{c}0.219 \\
(0.289)\end{array}$ & $\begin{array}{l}-0.307 \\
(0.607)\end{array}$ & $\begin{array}{l}-0.115 \\
(0.322)\end{array}$ & $\begin{array}{l}-1.149 \\
(0.721)\end{array}$ & $\begin{array}{l}0.338 \\
(0.409)\end{array}$ & $\begin{array}{c}0.320 \\
(0.730)\end{array}$ \\
\hline Policy zones & $\begin{array}{c}0.097 * * * \\
(0.011)\end{array}$ & $\begin{array}{c}0.104 * * * \\
(0.011)\end{array}$ & $\begin{array}{c}0.076^{* * *} \\
(0.011)\end{array}$ & $\begin{array}{c}0.076 * * * \\
(0.011)\end{array}$ & $\begin{array}{c}0.075 * * * \\
(0.013)\end{array}$ & $\begin{array}{c}0.071 * * * \\
(0.012)\end{array}$ \\
\hline FOE $\times$ Enc. policy & & & $\begin{array}{c}0.169 * * * \\
(0.042)\end{array}$ & $\begin{array}{c}0.146^{* * * *} \\
(0.042)\end{array}$ & $\begin{array}{c}0.233 * * * \\
(0.076)\end{array}$ & $\begin{array}{c}0.307 * * * \\
(0.082)\end{array}$ \\
\hline FOE $\times$ Res. policy & & & $\begin{array}{c}-0.278 * * * \\
(0.047)\end{array}$ & $\begin{array}{c}-0.215^{* * * *} \\
(0.045)\end{array}$ & $\begin{array}{c}-0.600 * * * \\
(0.087)\end{array}$ & $\begin{array}{c}-0.435 * * * \\
(0.093)\end{array}$ \\
\hline FOE $\times$ Court eff. & & & $\begin{array}{c}0.911 * * \\
(0.409)\end{array}$ & $\begin{array}{l}1.607 * * \\
(0.684)\end{array}$ & $\begin{array}{l}-0.716 \\
(0.468)\end{array}$ & $\begin{array}{l}-1.237^{*} \\
(0.706)\end{array}$ \\
\hline FOE $\times$ Zones & & & $\begin{array}{c}0.040 * * * \\
(0.006)\end{array}$ & $\begin{array}{c}0.038 * * * \\
(0.006)\end{array}$ & $\begin{array}{c}0.036 * * * \\
(0.006)\end{array}$ & $\begin{array}{c}0.041 * * * \\
(0.006)\end{array}$ \\
\hline Enc. Policy $\times$ Court eff. & & & & & $\begin{array}{c}-1.243 * * * \\
(0.420)\end{array}$ & $\begin{array}{c}-1.297 * * \\
(0.641)\end{array}$ \\
\hline Res. Policy $\times$ Court eff. & & & & & $\begin{array}{c}1.116^{* * * *} \\
(0.356)\end{array}$ & $\begin{array}{l}-0.574 \\
(0.569)\end{array}$ \\
\hline Enc. Policy $\times$ Zones & & & & & $\begin{array}{c}0.003 \\
(0.005)\end{array}$ & $\begin{array}{l}-0.000 \\
(0.006)\end{array}$ \\
\hline Res. Policy $\times$ Zones & & & & & $\begin{array}{l}-0.001 \\
(0.005)\end{array}$ & $\begin{array}{l}0.011^{*} \\
(0.006)\end{array}$ \\
\hline FOE $\times$ Enc. policy $\times$ Court eff. & & & & & $\begin{array}{c}3.463 * * * \\
(0.552)\end{array}$ & $\begin{array}{c}5.138 * * * \\
(0.779)\end{array}$ \\
\hline FOE $\times$ Res. policy $\times$ Court eff. & & & & & $\begin{array}{l}-1.681 * * * \\
(0.594)\end{array}$ & $\begin{array}{l}-0.891 \\
(0.947)\end{array}$ \\
\hline FOE $\times$ Enc. policy $\times$ Zones & & & & & $\begin{array}{l}-0.007 \\
(0.006)\end{array}$ & $\begin{array}{c}-0.016 * * \\
(0.006)\end{array}$ \\
\hline FOE $\times$ Res. policy $\times$ Zones & & & & & $\begin{array}{c}0.032 * * * \\
(0.007)\end{array}$ & $\begin{array}{c}0.018^{* * *} \\
(0.008)\end{array}$ \\
\hline $\operatorname{Ln}($ dist $)$ & $\begin{array}{c}-0.183 * * * \\
(0.038)\end{array}$ & $\begin{array}{c}-0.192 * * * \\
(0.045)\end{array}$ & $\begin{array}{l}-0.177 * * * \\
(0.039)\end{array}$ & $\begin{array}{l}-0.200 * * * \\
(0.046)\end{array}$ & $\begin{array}{c}-0.177 * * * \\
(0.039)\end{array}$ & $\begin{array}{c}-0.184 * * * \\
(0.044)\end{array}$ \\
\hline Coastal & $\begin{array}{c}0.852 * * * \\
(0.090)\end{array}$ & $\begin{array}{l}0.936^{* * * *} \\
(0.116)\end{array}$ & $\begin{array}{c}0.893 * * * \\
(0.091)\end{array}$ & $\begin{array}{l}1.054 * * * \\
(0.119)\end{array}$ & $\begin{array}{c}0.886 * * * \\
(0.091)\end{array}$ & $\begin{array}{c}1.009 * * * \\
(0.118)\end{array}$ \\
\hline Border & $\begin{array}{c}0.073 \\
(0.071)\end{array}$ & $\begin{array}{c}0.057 \\
(0.072)\end{array}$ & $\begin{array}{c}0.089 \\
(0.072)\end{array}$ & $\begin{array}{c}0.067 \\
(0.073)\end{array}$ & $\begin{array}{c}0.085 \\
(0.071)\end{array}$ & $\begin{array}{c}0.059 \\
(0.073)\end{array}$ \\
\hline $\operatorname{Ln}$ (pop density) & $\begin{array}{c}0.352 * * * \\
(0.040)\end{array}$ & $\begin{array}{c}0.346^{* * * *} \\
(0.041)\end{array}$ & $\begin{array}{c}0.355 * * * \\
(0.041)\end{array}$ & $\begin{array}{c}0.298 * * * \\
(0.038)\end{array}$ & $\begin{array}{c}0.355 * * * \\
(0.041)\end{array}$ & $\begin{array}{c}0.273 * * * \\
(0.037)\end{array}$ \\
\hline $\operatorname{Ln}(Y)$ & $\begin{array}{c}0.192 * * * \\
(0.061)\end{array}$ & $\begin{array}{c}0.155^{* *} \\
(0.063)\end{array}$ & $\begin{array}{l}0.214 * * * \\
(0.062)\end{array}$ & $\begin{array}{l}0.247 * * * \\
(0.058)\end{array}$ & $\begin{array}{l}0.210 * * * \\
(0.062)\end{array}$ & $\begin{array}{c}0.283^{* * * *} \\
(0.054)\end{array}$ \\
\hline Skill $\times$ college share & $\begin{array}{c}0.006^{* * * *} \\
(0.001)\end{array}$ & $\begin{array}{c}0.006 * * * \\
(0.001)\end{array}$ & $\begin{array}{c}0.006 * * * \\
(0.001)\end{array}$ & $\begin{array}{c}0.007 * * * \\
(0.001)\end{array}$ & $\begin{array}{c}0.006^{* * *} \\
(0.001)\end{array}$ & $\begin{array}{c}0.006^{* * * *} \\
(0.001)\end{array}$ \\
\hline Capital intensity $\times$ capital output ratio & $\begin{array}{c}0.040 * * * \\
(0.011)\end{array}$ & $\begin{array}{c}0.041 * * * \\
(0.012)\end{array}$ & $\begin{array}{c}0.041 * * * \\
(0.011)\end{array}$ & $\begin{array}{c}0.044 * * * \\
(0.013)\end{array}$ & $\begin{array}{c}0.040 * * * \\
(0.011)\end{array}$ & $\begin{array}{c}0.041 * * * \\
(0.012)\end{array}$ \\
\hline First stage $\mathrm{F}$ test & & 125.95 & & $>101.61$ & & $>35.69$ \\
\hline Constant, year and industrial dummies & Yes & Yes & Yes & Yes & Yes & Yes \\
\hline$N$ & 28,555 & 28,555 & 28,555 & 28,555 & 28,555 & 28,555 \\
\hline$R^{2}$ & 0.466 & 0.465 & 0.471 & 0.469 & 0.473 & 0.469 \\
\hline
\end{tabular}

Note: Variety is defined as an eight-digit HS product-destination country pair. The panel covers 29 provinces and 112 industries in 1997-2007. Province-year pair cluster robust standard errors are in parentheses. *, **, and *** indicate significance at the 10,5, and 1 percent levels. 
Table 3: Determinants of Processing Export: Alternative Measures of Extensive Margin

\begin{tabular}{|c|c|c|c|c|c|c|}
\hline \multirow[b]{2}{*}{ Independent variable } & \multicolumn{3}{|c|}{$\log (\text { Number of Variety })^{\mathrm{a}}$} & \multicolumn{3}{|c|}{$\log (\text { Extensive Margin Index })^{\mathrm{b}}$} \\
\hline & (1) & (2) & (3) & (4) & (5) & (6) \\
\hline FOE indicator & $\begin{array}{c}-0.384 * * * \\
(0.034)\end{array}$ & $\begin{array}{c}-0.758^{* * *} \\
(0.057)\end{array}$ & $\begin{array}{c}-0.785 * * * \\
(0.054)\end{array}$ & $\begin{array}{c}-0.392^{* * *} \\
(0.024)\end{array}$ & $\begin{array}{c}-0.656^{* * *} \\
(0.048)\end{array}$ & $\begin{array}{c}-0.661 * * * \\
(0.048)\end{array}$ \\
\hline Encouragement policy & $\begin{array}{c}0.091 * * * \\
(0.035)\end{array}$ & $\begin{array}{c}0.030 \\
(0.038)\end{array}$ & $\begin{array}{c}0.042 \\
(0.052)\end{array}$ & $\begin{array}{c}0.234 * * * \\
(0.044)\end{array}$ & $\begin{array}{c}0.207 * * * \\
(0.046)\end{array}$ & $\begin{array}{c}0.066 \\
(0.057)\end{array}$ \\
\hline Restriction policy & $\begin{array}{l}-0.017 \\
(0.038)\end{array}$ & $\begin{array}{c}0.094 * * \\
(0.042)\end{array}$ & $\begin{array}{c}0.176 * * * \\
(0.063)\end{array}$ & $\begin{array}{c}-0.126 * * * \\
(0.036)\end{array}$ & $\begin{array}{l}-0.040 \\
(0.040)\end{array}$ & $\begin{array}{c}-0.188 * * * \\
(0.060)\end{array}$ \\
\hline Court efficiency & $\begin{array}{c}0.239 \\
(0.649)\end{array}$ & $\begin{array}{l}-0.431 \\
(0.677)\end{array}$ & $\begin{array}{l}-0.117 \\
(0.662)\end{array}$ & $\begin{array}{l}-0.105 \\
(0.513)\end{array}$ & $\begin{array}{l}-0.783 \\
(0.587)\end{array}$ & $\begin{array}{c}0.017 \\
(0.541)\end{array}$ \\
\hline Policy zones & $\begin{array}{c}0.111^{* * *} \\
(0.013)\end{array}$ & $\begin{array}{c}0.083 * * * \\
(0.012)\end{array}$ & $\begin{array}{c}0.085^{* * *} \\
(0.014)\end{array}$ & $\begin{array}{c}0.077 * * * \\
(0.009)\end{array}$ & $\begin{array}{c}0.056 * * * \\
(0.008)\end{array}$ & $\begin{array}{c}0.042 * * * \\
(0.009)\end{array}$ \\
\hline FOE $\times$ Enc. policy & & $\begin{array}{c}0.186 * * * \\
(0.031)\end{array}$ & $\begin{array}{c}0.279 * * * \\
(0.058)\end{array}$ & & $\begin{array}{c}0.094 * * * \\
(0.027)\end{array}$ & $\begin{array}{c}0.180 * * * \\
(0.054)\end{array}$ \\
\hline FOE $\times$ Res. policy & & $\begin{array}{c}-0.270 * * * \\
(0.034)\end{array}$ & $\begin{array}{c}-0.412 * * * \\
(0.064)\end{array}$ & & $\begin{array}{c}-0.231 * * * \\
(0.036)\end{array}$ & $\begin{array}{c}-0.369 * * * \\
(0.075)\end{array}$ \\
\hline FOE $\times$ Court eff. & & $\begin{array}{c}2.322 * * * \\
(0.556)\end{array}$ & $\begin{array}{l}1.228 * * \\
(0.548)\end{array}$ & & $\begin{array}{l}1.206 * * \\
(0.475)\end{array}$ & $\begin{array}{c}-0.568 \\
(0.488)\end{array}$ \\
\hline FOE $\times$ Zones & & $\begin{array}{c}0.035^{* * *} * \\
(0.005)\end{array}$ & $\begin{array}{c}0.038 * * * \\
(0.005)\end{array}$ & & $\begin{array}{c}0.029 * * * \\
(0.004)\end{array}$ & $\begin{array}{c}0.032 * * * \\
(0.004)\end{array}$ \\
\hline Enc. Policy $\times$ Court eff. & & & $\begin{array}{l}-0.137 \\
(0.427)\end{array}$ & & & $\begin{array}{l}-0.781^{*} \\
(0.400)\end{array}$ \\
\hline Res. Policy $\times$ Court eff. & & & $\begin{array}{c}0.480 \\
(0.422)\end{array}$ & & & $\begin{array}{c}-0.904 * * \\
(0.445)\end{array}$ \\
\hline Enc. Policy $\times$ Zones & & & $\begin{array}{l}-0.002 \\
(0.004)\end{array}$ & & & $\begin{array}{c}0.013 * * * \\
(0.004)\end{array}$ \\
\hline Res. Policy $\times$ Zones & & & $\begin{array}{c}-0.009 * * \\
(0.005)\end{array}$ & & & $\begin{array}{c}0.018 * * * \\
(0.005)\end{array}$ \\
\hline FOE $\times$ Enc. policy $\times$ Court eff. & & & $\begin{array}{c}2.347 * * * \\
(0.583)\end{array}$ & & & $\begin{array}{c}2.957 * * * \\
(0.519)\end{array}$ \\
\hline FOE $\times$ Res. policy $\times$ Court eff. & & & $\begin{array}{l}-0.965 \\
(0.627)\end{array}$ & & & $\begin{array}{l}-0.132 \\
(0.730)\end{array}$ \\
\hline FOE $\times$ Enc. policy $\times$ Zones & & & $\begin{array}{c}-0.010 * * \\
(0.005)\end{array}$ & & & $\begin{array}{c}-0.010 * * \\
(0.004)\end{array}$ \\
\hline FOE $\times$ Res. policy $\times$ Zones & & & $0.014 * *$ & & & 0.010 \\
\hline First stage $\mathrm{F}$ test & 125.95 & $>101.61$ & $>35.69$ & 125.95 & $>101.61$ & $>35.69$ \\
\hline Constant, year and industrial dummies & Yes & Yes & Yes & Yes & Yes & Yes \\
\hline$N$ & 28,555 & 28,555 & 28,555 & 28,555 & 28,555 & 28,555 \\
\hline$R^{2}$ & 0.607 & 0.615 & 0.614 & 0.512 & 0.515 & 0.516 \\
\hline
\end{tabular}

\footnotetext{
Variety is defined as an eight-digit HS product-destination country pair.

${ }^{b}$ Variety is defined as an eight-digit HS product and extensive margin index uses Feenstra and Kee's (2008) method. Note: The panel covers 29 provinces and 112 industries in 1997-2007. All regressions are estimated by GMM, with instruments for court efficiency and its interactions. For brevity, we do not report the coefficients for the constant and the control variables specified in Table 2. Province-year pair cluster robust standard errors are in parentheses. *, **, and $* * *$ indicate significance at the 10,5 , and 1 percent levels.
} 
Table 4: Determinants of the Value of Processing Export

\begin{tabular}{|c|c|c|c|}
\hline \multirow[b]{2}{*}{ Independent variable } & \multicolumn{3}{|c|}{ Dependent variable: $\log ($ Export Value } \\
\hline & (1) & (2) & (3) \\
\hline FOE indicator & $\begin{array}{c}-0.668 * * * \\
(0.051)\end{array}$ & $\begin{array}{c}-1.328 * * * \\
(0.095)\end{array}$ & $\begin{array}{c}-1.248^{* * * *} \\
(0.097)\end{array}$ \\
\hline Encouragement policy & $\begin{array}{c}0.293 * * * \\
(0.076)\end{array}$ & $\begin{array}{c}0.253 * * * \\
(0.083)\end{array}$ & $\begin{array}{c}0.499 * * * \\
(0.113)\end{array}$ \\
\hline Restriction policy & $\begin{array}{c}-0.163 * * \\
(0.063)\end{array}$ & $\begin{array}{l}-0.037 \\
(0.069)\end{array}$ & $\begin{array}{c}0.007 \\
(0.110)\end{array}$ \\
\hline Court efficiency & $\begin{array}{c}0.317 \\
(1.021)\end{array}$ & $\begin{array}{l}-0.781 \\
(1.136)\end{array}$ & $\begin{array}{c}1.342 \\
(1.179)\end{array}$ \\
\hline Policy zones & $\begin{array}{c}0.128 * * * \\
(0.017)\end{array}$ & $\begin{array}{c}0.093 * * * \\
(0.017)\end{array}$ & $\begin{array}{c}0.114 * * * \\
(0.020)\end{array}$ \\
\hline FOE $\times$ Enc. policy & & $\begin{array}{c}0.123 * * \\
(0.061)\end{array}$ & $\begin{array}{c}0.051 \\
(0.111)\end{array}$ \\
\hline FOE $\times$ Res. policy & & $\begin{array}{c}-0.281 * * * \\
(0.062)\end{array}$ & $\begin{array}{c}-0.607 * * * \\
(0.132)\end{array}$ \\
\hline FOE $\times$ Court eff. & & $\begin{array}{c}2.226 * * * \\
(0.860)\end{array}$ & $\begin{array}{l}-1.445 \\
(0.982)\end{array}$ \\
\hline FOE $\times$ Zones & & $\begin{array}{c}0.066 * * * \\
(0.009)\end{array}$ & $\begin{array}{c}0.056 * * * \\
(0.009)\end{array}$ \\
\hline Enc. Policy $\times$ Court eff. & & & $\begin{array}{c}-2.107 * * \\
(0.880)\end{array}$ \\
\hline Res. Policy $\times$ Court eff. & & & $\begin{array}{c}0.196 \\
(0.822)\end{array}$ \\
\hline Enc. Policy $\times$ Zones & & & $\begin{array}{c}-0.034 * * * \\
(0.010)\end{array}$ \\
\hline Res. Policy $\times$ Zones & & & $\begin{array}{l}-0.010 \\
(0.008)\end{array}$ \\
\hline FOE $\times$ Enc. policy $\times$ Court eff. & & & $\begin{array}{c}6.701 * * * \\
(1.033)\end{array}$ \\
\hline FOE $\times$ Res. policy $\times$ Court eff. & & & $\begin{array}{c}-2.841 * * \\
(1.189)\end{array}$ \\
\hline FOE $\times$ Enc. policy $\times$ Zones & & & $\begin{array}{c}0.012 \\
(0.010)\end{array}$ \\
\hline FOE $\times$ Res. policy $\times$ Zones & & & $0.030^{* *}$ \\
\hline First stage $\mathrm{F}$ test & 125.95 & $>101.61$ & $>35.69$ \\
\hline Constant, year and industrial dummies & Yes & Yes & Yes \\
\hline$N$ & 28,555 & 28,555 & 28,555 \\
\hline$R^{2}$ & 0.477 & 0.482 & 0.483 \\
\hline
\end{tabular}

Note: The dependent variable is the log export value to all countries. The panel covers 29 provinces and 112 industries in 1997-2007. All regressions are estimated by GMM, with instruments for court efficiency and its interactions. For brevity, we do not report the coefficients for the constant and the control variables specified in Table 2. Province-year pair cluster robust standard errors are in parentheses. *,**, and *** indicate significance at the 10,5 , and 1 percent levels. 
Table 5: Determinants of Processing Export to High-income Countries

\begin{tabular}{|c|c|c|c|c|c|c|}
\hline \multirow[b]{2}{*}{ Independent variable } & \multicolumn{3}{|c|}{$\log (\text { Extensive Margin Index })^{a}$} & \multicolumn{3}{|c|}{$\log$ (Export Value) } \\
\hline & (1) & (2) & (3) & (4) & (5) & (6) \\
\hline FOE indicator & $\begin{array}{c}-0.409 * * * \\
(0.034)\end{array}$ & $\begin{array}{c}-0.769 * * * \\
(0.073)\end{array}$ & $\begin{array}{c}-0.808^{* * * *} \\
(0.071)\end{array}$ & $\begin{array}{c}-0.586^{* * *} \\
(0.052)\end{array}$ & $\begin{array}{c}-1.210^{* * * *} \\
(0.096)\end{array}$ & $\begin{array}{c}-1.195 * * * \\
(0.090)\end{array}$ \\
\hline Encouragement policy & $\begin{array}{c}0.266 * * * \\
(0.058)\end{array}$ & $\begin{array}{c}0.182 * * * \\
(0.059)\end{array}$ & $\begin{array}{l}0.172 * * \\
(0.077)\end{array}$ & $\begin{array}{c}0.242 * * * \\
(0.075)\end{array}$ & $\begin{array}{c}0.166^{* *} \\
(0.080)\end{array}$ & $\begin{array}{c}0.414 * * * \\
(0.110)\end{array}$ \\
\hline Restriction policy & $\begin{array}{c}-0.134 * * * \\
(0.052)\end{array}$ & $\begin{array}{l}-0.016 \\
(0.056)\end{array}$ & $\begin{array}{l}-0.137 * \\
(0.080)\end{array}$ & $\begin{array}{c}-0.187 * * * \\
(0.067)\end{array}$ & $\begin{array}{l}-0.045 \\
(0.073)\end{array}$ & $\begin{array}{c}0.044 \\
(0.115)\end{array}$ \\
\hline Court efficiency & $\begin{array}{c}0.440 \\
(0.601)\end{array}$ & $\begin{array}{l}-0.520 \\
(0.701)\end{array}$ & $\begin{array}{c}0.272 \\
(0.709)\end{array}$ & $\begin{array}{c}1.259 \\
(1.015)\end{array}$ & $\begin{array}{l}-0.143 \\
(1.125)\end{array}$ & $\begin{array}{c}1.469 \\
(1.171)\end{array}$ \\
\hline Policy zones & $\begin{array}{c}0.105^{* * *} \\
(0.011)\end{array}$ & $\begin{array}{c}0.080 * * * \\
(0.011)\end{array}$ & $\begin{array}{c}0.077 * * * \\
(0.012)\end{array}$ & $\begin{array}{c}0.132 * * * \\
(0.017)\end{array}$ & $\begin{array}{c}0.099 * * * \\
(0.017)\end{array}$ & $\begin{array}{c}0.120 * * * \\
(0.020)\end{array}$ \\
\hline FOE $\times$ Enc. policy & & $\begin{array}{c}0.173 * * * \\
(0.042)\end{array}$ & $\begin{array}{c}0.376 * * * \\
(0.086)\end{array}$ & & $\begin{array}{l}0.189 * * * \\
(0.064)\end{array}$ & $\begin{array}{c}0.179 \\
(0.115)\end{array}$ \\
\hline FOE $\times$ Res. policy & & $\begin{array}{c}-0.245 * * * \\
(0.046)\end{array}$ & $\begin{array}{c}-0.361 * * * \\
(0.089)\end{array}$ & & $\begin{array}{c}-0.297 * * * \\
(0.063)\end{array}$ & $\begin{array}{c}-0.486 * * * \\
(0.128)\end{array}$ \\
\hline FOE $\times$ Court eff. & & $\begin{array}{c}1.687 * * * \\
(0.647)\end{array}$ & $\begin{array}{l}-1.193 * \\
(0.689)\end{array}$ & & $\begin{array}{c}2.384 * * * \\
(0.831)\end{array}$ & $\begin{array}{l}-1.609 * \\
(0.952)\end{array}$ \\
\hline FOE $\times$ Zones & & $\begin{array}{c}0.033 * * * \\
(0.006)\end{array}$ & $\begin{array}{c}0.040 * * * \\
(0.006)\end{array}$ & & $\begin{array}{c}0.058 * * * \\
(0.008)\end{array}$ & $\begin{array}{c}0.054 * * * \\
(0.008)\end{array}$ \\
\hline Enc. Policy $\times$ Court eff. & & & $\begin{array}{l}-0.616 \\
(0.668)\end{array}$ & & & $\begin{array}{l}-1.583^{*} \\
(0.895)\end{array}$ \\
\hline Res. Policy $\times$ Court eff. & & & $\begin{array}{c}-1.234 * * \\
(0.573)\end{array}$ & & & $\begin{array}{l}-0.047 \\
(0.849)\end{array}$ \\
\hline Enc. Policy $\times$ Zones & & & $\begin{array}{l}-0.000 \\
(0.005)\end{array}$ & & & $\begin{array}{c}-0.033 * * * \\
(0.010)\end{array}$ \\
\hline Res. Policy $\times$ Zones & & & $\begin{array}{l}0.011^{*} \\
(0.006)\end{array}$ & & & $\begin{array}{l}-0.013 \\
(0.009)\end{array}$ \\
\hline FOE $\times$ Enc. policy $\times$ Court eff. & & & $\begin{array}{l}5.250 * * * \\
(0.879)\end{array}$ & & & $\begin{array}{c}7.078 * * * \\
(1.118)\end{array}$ \\
\hline FOE $\times$ Res. policy $\times$ Court eff. & & & $\begin{array}{l}-0.103 \\
(0.998)\end{array}$ & & & $\begin{array}{l}-1.806 \\
(1.216)\end{array}$ \\
\hline FOE $\times$ Enc. policy $\times$ Zones & & & $\begin{array}{l}-0.020 * * * \\
(0.007)\end{array}$ & & & $\begin{array}{c}0.004 \\
(0.010)\end{array}$ \\
\hline FOE $\times$ Res. policy $\times$ Zones & & & $\begin{array}{c}0.010 \\
(0.008)\end{array}$ & & & $\begin{array}{c}0.018 \\
(0.012)\end{array}$ \\
\hline First stage $\mathrm{F}$ test & 128.31 & $>99.88$ & $>37.31$ & 128.31 & $>99.88$ & $>37.31$ \\
\hline Constant, year and industrial dummies & Yes & Yes & Yes & Yes & Yes & Yes \\
\hline$N$ & 27,022 & 27,022 & 27,022 & 27,022 & 27,022 & 27,022 \\
\hline$R^{2}$ & 0.461 & 0.465 & 0.465 & 0.482 & 0.487 & 0.487 \\
\hline
\end{tabular}

\footnotetext{
${ }^{a}$ Variety is defined as an eight-digit HS product-country pair and extensive margin index uses Feenstra and Kee's (2008) method.

Note: The sample covers China's processing export to high-income countries. The panel covers 29 provinces and 112 industries in 1997-2007. All regressions are estimated by GMM, with instruments for court efficiency and its interactions. For brevity, we do not report the coefficients for the constant and the control variables specified in Table 2. Province-year pair cluster robust standard errors are in parentheses. *,**, and *** indicate significance at the 10 , 5 , and 1 percent levels.
} 


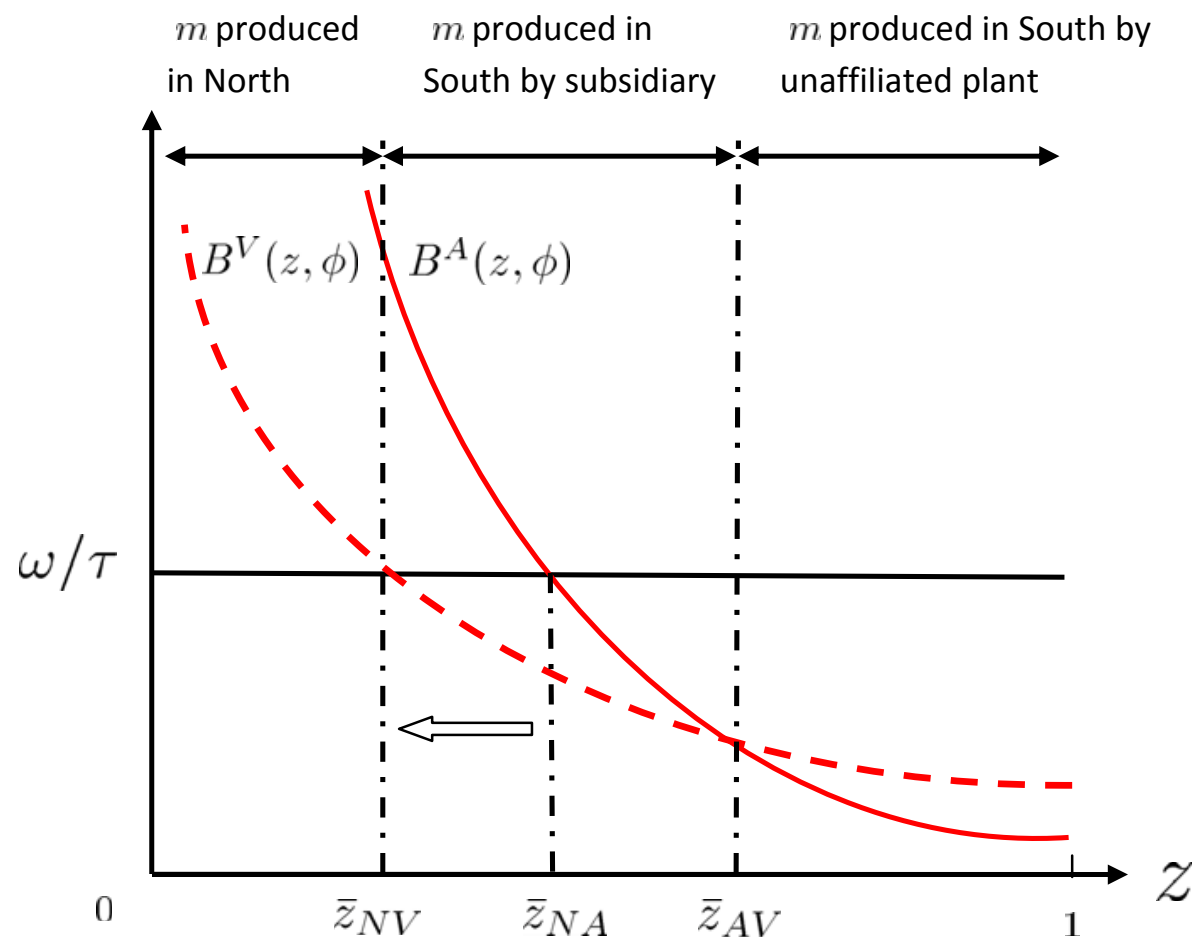

Figure 1: Effect of Ownership Liberalization on the Extensive Margin 


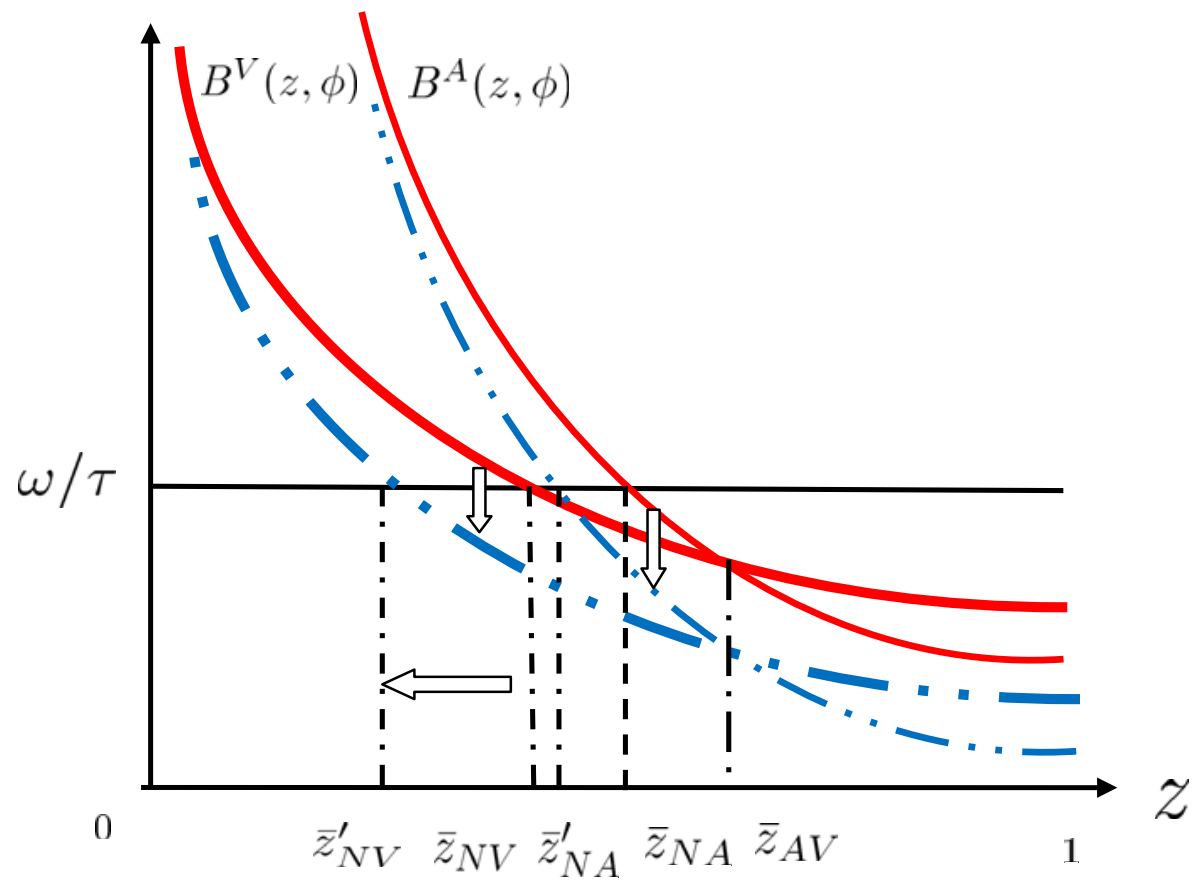

Figure 2: Effect of Contract Enforcement on the Extensive Margin

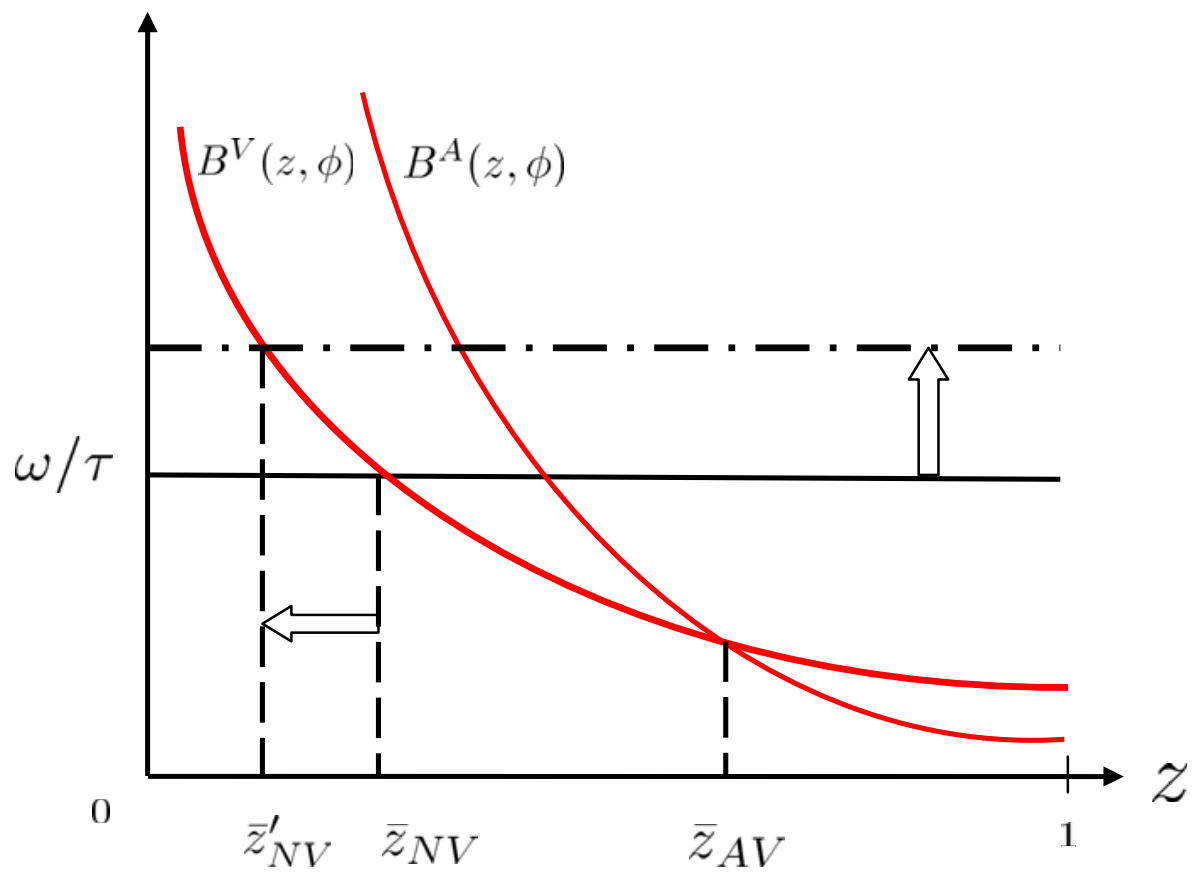

Figure 3: Effect of Trade Cost Reduction on the Extensive Margin 


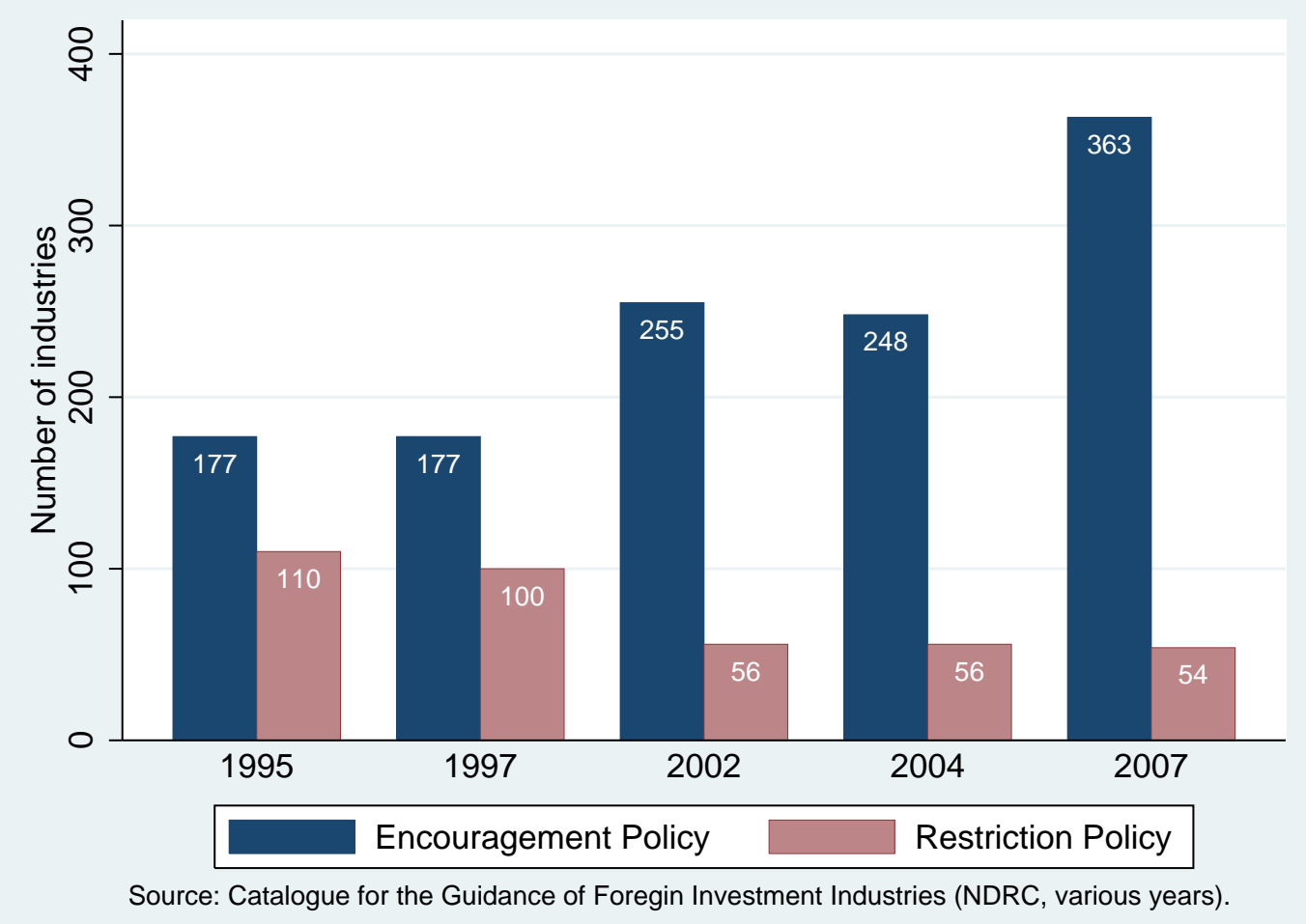

Figure 4: Measure of Ownership Liberalization 1995-2007 


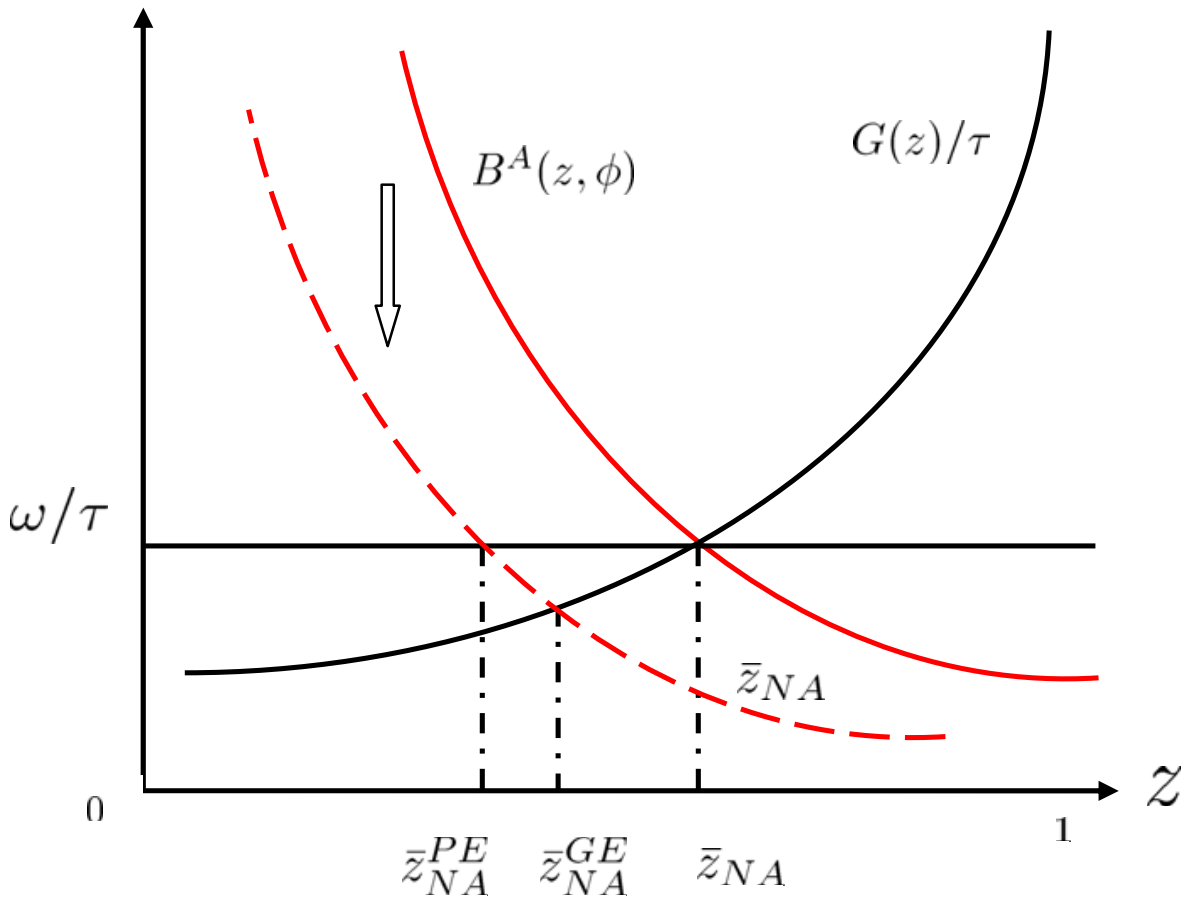

Figure 5: General Equilibrium Effect on Extensive Margin Growth 